H. Kent Baker, CFA

E. Theodore Veit, CFA

Michael R. Murphy, CFA

\title{
Ethics in the Investment Profession: An International Survey
}

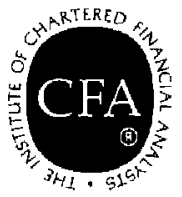

The Research Foundation of The Institute of Chartered Financial Analysts 


\section{The Research Foundation of The Institute of Chartered Financial Analysts}

\section{Board of Trustees \\ 1994-95}

Chair

Eugene C. Sit, CFA

Sit Investment Associates, Inc.

Vice Chair

George W. Noyes, CFA

Standish, Ayer \& Wood, Inc.

President and $C E O$

Thomas A Bowman, CFA

AIMR

Senior Vice President and Chief

Operating Officer

Katrina F. Sherrerd, CFA

AIMR

Gary P. Brinson, CFA

Brinson Partners, Inc.

Thomas L. Hansberger, CFA

Hansberger Global Investors, Inc.

Lea B. Hansen, CFA

John L. Maginn, CFA

Mutual of Omaha Insurance Company
Frederick L Muller, CFA

Atlanta Capital Management Company

Ian R. O'Reilly, CFA

Wood Gundy Inc.

John W. Peavy III, CFA

Founders Trust

Stephen A Ross

Yale University

Fred H. Speece, Jr., CFA

Speece, Lewis \& Thorson, Inc.

Walter P. Stern, CFA

Capital Group International, Inc.

Michael F. Theobald

University of Birmingham

James R Vertin, CFA

Alpine Counselors

Eliot P. Williams, CFA

Williams Investment Counselors

Brian F. Wruble, CFA

Delaware Management Company

\section{Review Board}

Research Director

Keith C. Brown, CFA

University of Texas, Austin

\section{Chris B. Barry}

Texas Christian University

Gerald O. Bierwag

Florida International University

Brian R. Bruce

State Street Global Advisors

Joanne M. Hill, Ph.D.

Goldman, Sachs \& Company

Mark P. Kritzman, CFA

Windham Capital Management

Scott L Lummer, CFA

Ibbotson Associates
William Reichenstein Baylor University

Frank K. Reilly, CFA

University of Notre Dame

Richard Roll, Ph.D.

University of California, Los Angeles

Gary G. Schlarbaum, CFA

Miller, Anderson \& Sherrerd

Brian D. Singer, CFA

Brinson Partners, Inc.

Eliot P. Williams, CFA

Williams Investment Counselors

Arnold S. Wood

Martingale Asset Management 
H. Kent Baker, CFA

The American University

$E$. Theodore Veit, CFA

Rollins College

Michael R. Murphy, CFA

Sceptre Investment Counsel, Ltd.

\section{Ethics in the Investment Profession: An International Survey}

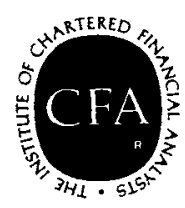

The Research Foundation of

The Institute of Chartered Financial Analysts 


\section{Research Foundation Publications}

Active Currency Management

by Murali Ramaswami

Analysts' Eamings Forecast Accuracy in Japan and the United States

by Robert M. Conroy, Robert S. Harris, and Young S. Park

Canadian Stocks, Bonds, Bills, and Infiation: 1950-1987

by James $\mathrm{E}$. Hatch and Robert E. White

Closed-Form Duration Measures and Strategy Applications

by Nelson J. Lacey and Sanjay K. Nawalkha

Corporate Bond Rating Drift: An Examination of Credit Quality Rating Changes over Time

by Edward I. Altman and Duen Li Kao

Corporate Governance and Firm Pefformance by Jonathan M. Karpoff, M. Wayne Marr, Jr., and Morris G. Danielson

Default Risk, Mortality Rates, and the Penformance of Corporate Bonds by Edward I. Altman

Durations of Nondefault-Free Securities by Gerald $O$. Bierwag and George $G$. Kaufman

Earnings Forecasts and Share Price Reversals by Werner F.M. De Bondt

The Effect of Illiquidity on Bond Price Data: Some Symptoms and Remedies

by Oded Sarig and Arthur Warga

Equity Trading Costs

by Hans R Stoll

Ethics, Faimess, Efficiency, and Financial Markets by Hersh Shefrin and Meir Statman

Ethics in the Investment Profession: A Survey

by $\mathrm{E}$. Theodore Veit, CFA, and Michael $\mathrm{R}$. Murphy, CFA

The Founders of Modern Finance: Their Prize-Winning Concepts and 1990 Nobel Lectures

Franchise Value and the Price/Eamings Ratio by Martin L. Leibowitz and Stanley Kogelman

\author{
Fundamental Considerations in Cross-Border \\ Investment: The European View \\ by Bruno Solnik \\ Global Asset Management and Performance Attribution \\ by Denis S. Karnosky, Ph.D., and Brian D. \\ Singer, CFA \\ Initial Public Offerings: The Role of Venture Capitalists \\ by Joseph T. Lim and Anthony Saunders \\ Managed Futures and Their Role in Investment Pontfolios \\ by Don M. Chance, CFA \\ The Modern Role of Bond Covenants \\ by Ileen B. Malitz
}

A New Method for Valuing Treasury Bond Futures Options by Ehud I. Ronn and Robert R. Bliss, Jr.

A New Perspective on Asset Allocation by Martin L. Leibowitz

Options and Futures: A Tutorial

by Roger G. Clarke

The Poison Pill Anti-Takeover Defense: The

Price of Strategic Deterrence

by Robert F. Bruner

A Practitioner's Guide to Factor Models

Predictable Time-Varying Components of Intemational Asset Returus

by Bruno Solnik

Program Trading and Systematic Rish by A.J. Senchack, Jr., and John D. Martin

The Role of Risk Tolerance in the Asset Allocation Process: A New Perspective

by W.V. Harlow III, CFA, and Keith C. Brown, CFA

Selecting Superior Securities

by Marc $R$. Reinganum

Stock Market Structure, Volatility, and Volume by Hans R. Stoll and Robert E. Whaley

Stocks, Bonds, Bills, and Inflation: Historical Retums (1926-1987)

by Roger G. Ibbotson and Rex A. Sinquefield

(Published with Irwin Professional Publishing) 
Ethics in the Investment Profession: An International Survey 
(C) 1995 The Research Foundation of the Institute of Chartered Financial Analysts

All rights reserved. No part of this publication may be reproduced, stored in a retrieval system, or transmitted, in any form or by any means, electronic, mechanical, photocopying, recording, or otherwise, without the prior written permission of the copyright holder.

This publication is designed to provide accurate and authoritative information in regard to the subject matter covered. It is sold with the understanding that the publisher is not engaged in rendering legai, accounting, or other professional service. If legal advice or other expert assistance is required, the services of a competent professional should be sought.

ISBN 10-digit: 0-943205-29-8 ISBN 13-digit: 978-0-943205-29-8

Printed in the United States of America

January 1995 


\section{Mission}

The mission of the Research Foundation is to identify, fund, and publish research material that:

- expands the body of relevant and useful knowledge available to practitioners;

- assists practitioners in understanding and applying this knowledge; and

- enhances the investment management community's effectiveness in serving clients.

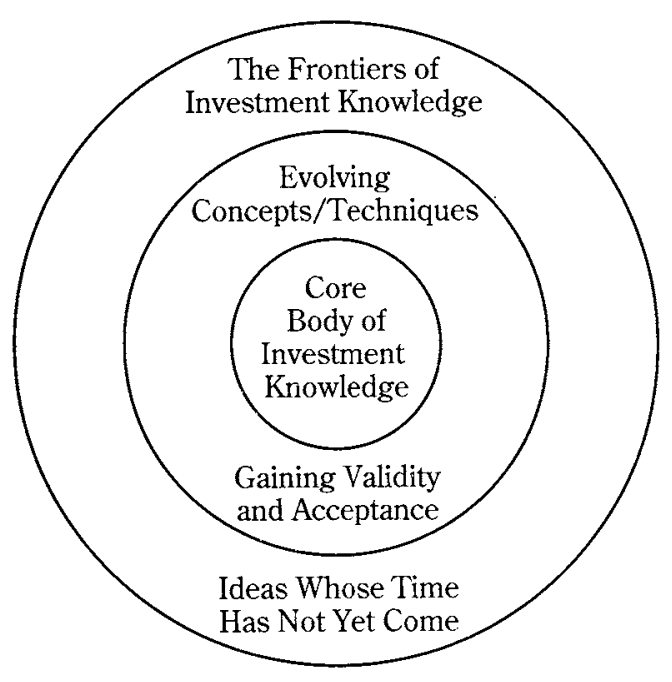

The Research Foundation of

The Institute of Chartered Financial Analysts

P.O. Box 3668

Charlottesville, Virginia 22903

U.S.A.

Telephone: 804/980-3644

Fax: 804/980-3634 


\section{Table of Contents}

Acknowledgements .................. vi

Foreword $\ldots \ldots \ldots \ldots \ldots \ldots \ldots \ldots$ vii

Chapter 1. Introduction . . . . . . . . . . . . 1

Chapter 2. The Survey $\ldots \ldots \ldots \ldots \ldots \ldots \ldots \ldots \ldots . \ldots \ldots$

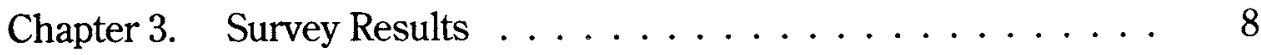

Chapter 4. Summary and Conclusions $\ldots \ldots \ldots \ldots \ldots \ldots . \ldots . \ldots . \ldots$

Appendix: Ethics in the Investment Profession Survey . . . . . . . 42

References . . . . . . . . . . . . . . . 49 


\section{Acknowledgements}

We would like to acknowledge the Research Foundation of the Institute of Chartered Financial Analysts for funding this project. The American University and Rollins College also provided administrative and computer support. Special thanks go to Michael Mirsky and Husein Abdul-Hamid at The American University and to Sue Crabill at Rollins College. Many others contributed to the success of this survey, including those people who reviewed the questionnaire before it was mailed.

Finally, this project would not have been possible without the participation of the respondents who shared their thoughts and experiences with us. The exceptionally high response rate shows that securities analysts and portfolio managers are very interested in improving the ethical behavior and enhancing the image of the investment profession.

H. Kent Baker, CFA

E. Theodore Veit, CFA

Michael R. Murphy, CFA 


\section{Foreword}

The importance of ethics and professional conduct to the Association for Investment Management and Research cannot be overestimated. A code of ethics and standards of professional conduct have been prime concerns of the Financial Analysts Foundation and the Institute of Chartered Financial Analysts and are the cornerstones of our Professional Conduct Program and Performance Presentation Standards.

This study is the third study of ethics in the investment profession published by the Research Foundation of the ICFA. The first, Professional Standards in Investment Management, was conducted by W. Scott Bauman in 1980. In 1992, the Research Foundation published a survey of professional ethics in the United States and Canada called Ethics in the Investment Profession: A Survey, by E. Theodore Veit, CFA, and Michael R. Murphy, CFA.

The 1992 book noted the importance of understanding the ethical precepts and practices of our colleagues working in "increasingly borderless financial markets." Based on the expanding international nature of the investment industry, this understanding is more important today than ever before. The time is thus ripe for a study of the ethical precepts and practices of the international profession.

The study reported in this volume makes a start. It reports the results of surveying AIMR investment professionals working in the eight non-North American countries with the highest number of AIMR members. The survey represents the opinions of 718 professionals, which in turn, represent a remarkably high response rate of 75 percent to the questionnaires distributed.

One of the most valuable contributions of this study is the comparisons of these non-North Americans' responses with the North Americans' responses to similar questions asked of the American and Canadians surveyed for the preceding book. Comparison is facilitated by use of the same basic questionnaire in both surveys. A most significant finding for those, like AIMR, who are trying to nurture ethical behavior through standards is the difference of opinions between the N.A. and non-N.A. respondents about which deterrents to unethical behavior are most effective. The two most important deterrents to unethical behavior noted by non-North Americans are concern about disciplinary action by the professional's employer and concern about sanctions from government agencies. In the N.A. survey, the two most important deterrents were concern about government sanctions and moral/religious beliefs. Non-N.A. respondents rated concerns about sanctions from self-regulatory organizations and a published code of ethics as greater deterrents than 
the North Americans did. North Americans cited moral and religious beliefs and concern that family or friends will find out as greater deterrents than the non-North Americans. Perhaps predictably, codes of ethics and compliance officers were less evident in places of employment outside North America.

One set of findings suggests a call to action for managers of investment professionals worldwide. The non-North Americans' responses reveal a high incidence of ethical violations, especially those involving inside information. The conclusion is that current deterrents are not sufficient to control behavior. Two remedies suggested by the responses are for senior managers to set stronger examples of ethical behavior and for employing firms to provide effective training programs in applying standards.

We are pleased to make available this valuable and timely Research Foundation monograph. It extends the sparse literature on professional ethics in the investment profession and provides insights that practitioners can use in dealing with colleagues around the world.

Katrina F. Sherrerd,.CFA Senior Vice President and Chief Operating Officer The Research Foundation of The Institute of Chartered Financial Analysts 


\section{Introduction}

The need for improved business ethics in North America is a matter of great concern to both academics and practitioners. Because of this concern, more than 20 academic institutions in North America alone have established centers devoted, at least partially, to the study, teaching, and enhancement of business ethics. ${ }^{1}$ North American governments are increasingly calling on firms to improve their ethical behavior or face expanded regulation. Recently, Commissioner J. Carter Beese, Jr., of the U.S. Securities and Exchange Commission (SEC) challenged brokerage firms to change their broker compensation systems because the SEC believes the typical current system encourages brokers to cheat their customers. He warned brokerage firms, "If you don't eliminate [rogue brokers], then we will, and those with supervisory responsibility will be held accountable" (Harlan 1993).

The investment profession is highly scrutinized for the presence or absence of ethical standards and behavior. One reason is the high level of expertise needed to manage (or provide advice on managing) assets or portfolios of assets. Because investing requires specialized knowledge, most investors rely on investment professionals, but the relationship between investors and investment professionals may create conflicts of interest. A second reason for the intense scrutiny of the investment profession is the profession's history of heavily publicized ethical and legal abuses.

Despite the public's widespread perception that investment professionals lack good ethics, some industry observers disagree. In a survey of affluent investors by Sommar (1991), 80 percent of respondents believed their bro-

\footnotetext{
${ }^{1}$ The following are examples of ethics centers in North America: Center for Applied and Professional Ethics, University of Tennessee; Center for Ethics Across the University, Loyola University of Chicago; Center for Management Ethics in Action, Boston College; Center for Professional Ethics, Manhattan College; Center for the Study of Ethics in the Professions, Illinois Institute of Technology; Center for the Teaching and Study of Applied Ethics, University of Nebraska, Lincoln; Ethics Institute, Capital University; Ethics Resource Center, Inc., Washington, D.C.; Kegley Institute of Ethics, California State University, Bakersfield; Poynter Center for the Study of Ethics and American Institutions, Indiana University; Society for Business Ethics, Rosemont College; and Westminster Institute for Ethics and Human Values, London, Ontario.
} 
kers acted ethically and 78 percent said their brokers did not use high-pressure sales tactics. Markowitz (1992), the father of portfolio theory, argues that, on a per capita basis with comparable opportunity, people in the financial industry do not break any more laws than people in other industries.

Nevertheless, the perception exists that the business community lacks ethical conduct, and this perception extends beyond North America. In Japan, the resignations of Yoshihisa Tabuchi, president of Nomura Securities, and Takuya Iwasaki, president of Nikko Securities, resulted from questionable activities by their respective firms ("Fallen Angels" 1991). In the Netherlands, Willem Scherpenhuijsen Rom, chair of Internationale Nederlanden Group, resigned only a few weeks after taking office because of allegations of unethical practices (King 1992). In 1987, the chair of the Hong Kong Stock Exchange was arrested on corruption charges (Dunleavy 1991).

In London, Ernest Saunders and three other executives of Guinness PLC were convicted of conspiracy, theft, and false accounting for their role in the takeover of Distillers Company PLC, a Scottish liquor firm. Saunders was accused of arranging secret, illegal securities transactions to inflate the price of Guinness common stock in order to sweeten his firm's takeover offer. Some call this case the biggest corporate scandal in Great Britain's history (Walsh 1991).

Evidence shows that ethical standards differ among the people of different countries. One often-cited report involves a difference between Japanese workers and U.S. workers (Cohen, Pant, and Sharp 1992). As collectivists, Japanese workers value conformity to the group. American workers are more individualistic than their Japanese counterparts. Therefore, Americans are likely to view a superior's pressure on a subordinate to cover up a bribe as coercion. Japanese workers may be more willing than American workers to obey their superiors and help save face for the company and their work group.

Cohen, Pant, and Sharp (1992) studied cultural and socioeconomic factors that could adversely affect the acceptance and implementation of an international professional code of ethics. The basis of their study was Guidelines on Ethics for Professional Accountants. The authors concluded that ethical guidelines do not cross borders well when they reflect only the ethical and cultural standards of the country that developed the guidelines. Cohen et al. advocated involving individuals from all participating countries in the development of general professional guidelines for ethics.

Some people argue that ethical behavior worldwide has exhibited a marked decline since the 1980s. As Dimma (1991) notes, "Heaven no longer provides a strong incentive to do good these days, especially to the pragmatists of the world, including hard-bitten corporate raiders, investment bankers, politi- 
cians, and business people." Cree and Baring (1991), in a study of accounting students in Australia, found that 67 percent of those surveyed, despite facing the risk of imprisonment, were willing to trade securities based on inside information. This perceived decline in ethics may call for increased reliance on rewards and sanctions, corporate codes of ethics, and guidance from professional organizations.

The purpose of the survey reported here was to investigate the ethical attitudes, perceptions, and practices of investment professionals from a variety of countries. Analysis of this information and comparison of information from North American and non-North American sources is intended to reveal differences and similarities in ethics around the world.

\section{Previous Studies}

Few studies exist of ethics on the part of investment professionals. Most of the extant literature documents past ethics violations or presents ethical guidelines for investment professionals (see, for example, Casey 1988, Frankhauser and Frye 1988, Gillis and Kern 1986, and Morley 1987). Although this information is useful, it does little to define the current state of ethical behavior in the investment profession.

The research on insider trading is extensive, but it focuses on insider trading as carried out by corporate officials, not by investment professionals (see, for example, Lee, Mikkelson, and Partch 1992). Studies of insider trading that focus on investment professionals are difficult to conduct because of a general lack of data. Unlike corporate officials, who must report stock holdings and trades to the SEC, investment professionals are unlikely to document such activities as using inside information.

One study of business ethics in general found that several variables are good predictors of ethical beliefs and decisions about insider trading (Terpstra, Reyes, and Bokor 1991). The authors hypothesized that ethical decisions are a function of personal variables, situational variables, and the interaction of these variables. The results of their study supported that contention.

Two studies have reported the results of surveys of investment professionals. One survey (Bauman 1980) asked members of the Financial Analysts Federation (FAF) and the Institute of Chartered Financial Analysts (ICFA) what they would do under various hypothetical circumstances, all of which posed ethical dilemmas. The central theme of the study was to decide whether FAF/ICFA members comply with the joint Standards of Professional Conduct 
espoused by the two organizations. ${ }^{2}$ Those surveyed had various job titles, including portfolio manager, supervisor of portfolio managers, and supervisor of securities research analysts. Bauman concluded that financial analysts generally have a commitment to "professionalizing" their practices, maintaining high standards of conduct, and protecting the public interest.

The second study (Veit and Murphy 1992) reported the results of a survey of securities analysts in North America who are members of the Association for Investment Management and Research (AIMR). This survey asked participants to describe their experiences and offer their opinions on various ethical issues. The study had several goals:

- to determine the level of analysts' compliance with the standards of practice required by law and the ethical standards promoted by professional organizations;

- to identify the nature of violations of legal and ethical standards that may occur among analysts;

- to document the attitudes of analysts concerning the ethical behavior of investment professionals compared with other professionals;

- to report the opinions of analysts about appropriate sources of ethics education;

- to report the opinions of analysts on past and future trends in ethical behavior in the investment profession; and

- to present evidence about the ethical guidance provided to investment professionals by senior managers and by the policies of employing firms.

This survey provided much information about analysts living in North America and is the model for the current study, which is intended to provide similar information about investment professionals outside North America.

\section{The Current Study}

Much information now exists about the ethics-related attitudes and experiences of North American securities analysts (those who are AIMR members), but similar information about investment professionals outside North America is sparse. The current study adds to this information by surveying investment professionals employed in eight non-North American countries and reporting the results.

Several research issues motivated the study. First, evidence suggests that

\footnotetext{
2Although the FAF and ICFA have since Bauman's 1980 study merged into a single organization, the Association for Investment Management and Research, each organization maintains its own identity.
} 
environment influences an individual's view of ethics. Evidence also suggests that professional codes of ethics do not cross borders easily. Therefore, differences may exist among countries as to what constitutes ethical or legal behavior. The current study hopes to offer insights into these issues. 


\section{The Survey}

The sample for this study was drawn from AIMR's total worldwide membership of about 24,000 with the exclusion of members in North America (for a total of 1,081 international members). This approach was chosen because, although not all analysts and other investment professionals in the countries sampled belong to AIMR, AIMR has more investment professionals associated with it than does any other investment organization.

The researchers selected the eight countries outside North America having the most AIMR members who identified themselves as securities analysts or portfolio managers. Four countries are Asian (Hong Kong, Japan, Singapore, and Thailand), and the other four are Australia, South Africa, Switzerland, and the United Kingdom. Table 1 shows the breakdown by country for the 964 securities analysts and portfolio managers to whom surveys were sent.

To enable comparisons between the results of the current survey with those of the earlier survey (Veit and Murphy 1992), the same basic questionnaire used in 1992 was used for this international study. Some tailoring was necessary, however, to reflect different terminology among the countries surveyed. Investment professionals from each country, including portfolio managers and research analysts, reviewed this study's questionnaire and suggested changes for clarity, which were made for each country questionnaire.

All questionnaires were written in English because, for several reasons, everyone in the sample was believed to be fluent in English. First, all survey participants were members of AIMR, which is based in North America and conducts all its business in English. Second, most survey participants were Chartered Financial Analyst (CFA) charterholders or candidates, who typically must complete their written examinations in English.

The initial survey was mailed on June 21, 1993, and was followed three weeks later by another letter and survey to nonrespondents. Of 964 questionnaires mailed, 958 were deliverable and 718 usable responses were received. After subtracting undeliverable questionnaires, the response rate was thus 74.9 percent. Not all 718 usable responses contained answers to every question, which lowers the response rate slightly on some questions. The appendix contains a copy of the questionnaire and the number of participants who 
TABLE 1. Survey Response Rates by Country

\begin{tabular}{lcccc}
\hline Country & Mailed & Delivered & Responded & $\begin{array}{c}\text { Response } \\
\text { Rate }\end{array}$ \\
\hline Asian & & & & \\
$\quad$ Hong Kong & 162 & 162 & 130 & $80.2 \%$ \\
Japan & 138 & 138 & 95 & 68.8 \\
Singapore & 219 & 216 & 150 & 69.4 \\
Thailand & 63 & 63 & 39 & \\
Other & & & & \\
$\quad$ Australia & 44 & 44 & 33 & 75.0 \\
South Africa & 70 & 68 & 51 & 75.0 \\
Switzerland & 151 & 150 & 128 & $\mathbf{7 8 . 3}$ \\
$\quad$ United Kingdom & $\underline{117}$ & $\underline{117}$ & $\underline{92}$ & 74.9 \\
$\quad$ Total & 964 & 958 & & \\
\hline
\end{tabular}

responded to each question.

As with all surveys, this one had the potential of nonresponse bias. The assurance of anonymity was intended to reduce this potential bias, however, and the unusually high response rate gives some assurance that nonresponse bias was minimized.

Two reasons warrant much caution in generalizing the findings to other investment professionals. First, the sample represents only a small percentage of the investment professionals in the countries surveyed. Second, all respondents hold membership in AIMR, implying greater awareness of and adherence to ethical behavior in the profession. However, the researchers believe that the results adequately represent the investment professionals surveyed. 


\section{Survey Results}

The responses of each survey participant were first entered into a data base. (To maintain anonymity, individual respondents and their employers were not identified by name.) After the results for the international sample were recorded, these results were compared with the responses to a survey of investment professionals in the United States and Canada (Veit and Murphy 1992), which was conducted during the fall of 1990 and received 400 usable responses from 894 potential respondents.

In the remainder of this monograph, the current study will be referred to as the international survey and the earlier study as the North American survey.

Nonparametric tests were used to decide whether significant differences existed between various responses to the international and North American surveys. For all the chi-square tests, the null hypothesis was that the responses between any two questions or groups do not differ significantly. The Spearman rank correlation coefficient was computed to measure the association between two sets of rankings in the international and North American surveys. The 5 percent significance level was used for all statistical tests.

\section{Respondent and Firm Attributes}

Understanding the characteristics of the survey respondents and their employing firms is important when interpreting the results. Table 2 presents some attributes of the respondents to the international survey and of their firms. The key attributes are as follows:

- More than three-quarters of the respondents are male.

- More than three-quarters of the respondents are between 26 and 35 years old.

- Almost half the respondents have less than five years' experience in the investment business.

- For about half the respondents, the highest earned academic degree is a bachelor's degree; 44 percent of respondents have a master's degree.

- About three-quarters of the respondents are candidates in the CFA program.

- More than half the respondents operate on the buy side of investment 
TABLE 2. Attributes of Survey Respondents and Employers: Full Sample

\begin{tabular}{|c|c|c|c|c|}
\hline \multirow[b]{2}{*}{ Attribute } & \multicolumn{2}{|c|}{ International } & \multicolumn{2}{|c|}{ North American } \\
\hline & Number & Percent & Number & Percent \\
\hline \multicolumn{5}{|l|}{ Gender } \\
\hline Male & 557 & $77.6 \%$ & 300 & $75.0 \%$ \\
\hline \multirow[t]{2}{*}{ Female } & $\underline{161}$ & 22.4 & $\underline{100}$ & 25.0 \\
\hline & 718 & 100.0 & 400 & $\overline{100.0}$ \\
\hline \multicolumn{5}{|l|}{ Age $^{\mathrm{a}}$} \\
\hline Under 25 & 44 & 6.1 & 5 & 1.3 \\
\hline 26 to 35 & 562 & 78.3 & 192 & 48.0 \\
\hline 46 to 55 & 105 & 14.6 & 102 & 25.5 \\
\hline 56 to 65 & 5 & 0.7 & 62 & 15.5 \\
\hline \multirow[t]{3}{*}{ Over 65} & 2 & 0.3 & 33 & 8.3 \\
\hline & $\underline{0}$ & 0.0 & 6 & 1.5 \\
\hline & $\overline{718}$ & $\overline{100.0}$ & $\overline{400}$ & $\overline{100.0}$ \\
\hline \multicolumn{5}{|c|}{$\begin{array}{l}\text { Number of years employed in } \\
\text { investment business }\end{array}$} \\
\hline Less than 5 & 337 & 47.3 & 80 & 20.1 \\
\hline 5 to 9 & 268 & 37.6 & 138 & 34.6 \\
\hline 10 to 14 & 91 & 12.8 & 59 & 14.8 \\
\hline 15 to 19 & 8 & 1.1 & 34 & 8.5 \\
\hline 20 to 24 & 4 & 0.6 & 44 & 11.0 \\
\hline 25 to 29 & 3 & 0.4 & 18 & 4.5 \\
\hline \multirow[t]{2}{*}{30 or more } & 1 & 0.1 & 26 & 6.5 \\
\hline & $\overline{712}$ & $\overline{100.0}$ & $\overline{399}$ & $\overline{100.0}$ \\
\hline \multicolumn{5}{|c|}{ Highest academic degree earmed ${ }^{a}$} \\
\hline High school diploma & 8 & 1.1 & 3 & 0.8 \\
\hline Bachelor's degree & 345 & 48.2 & 123 & 30.8 \\
\hline Master's degree & 315 & 44.0 & 258 & 64.7 \\
\hline Doctorate & 17 & 2.4 & 10 & 2.5 \\
\hline \multirow[t]{2}{*}{ Other } & 31 & 4.3 & 5 & 1.3 \\
\hline & $\overline{716}$ & $\overline{100.0}$ & $\overline{399}$ & $\overline{100.0}$ \\
\hline \multicolumn{5}{|l|}{ CFA designation earned } \\
\hline CFA & 158 & 22.0 & 280 & 70.0 \\
\hline CFA candidate & 544 & 75.9 & NA & NA \\
\hline \multirow{2}{*}{ Neither } & 15 & 2.1 & NA & NA \\
\hline & $\overline{717}$ & 100.0 & & \\
\hline \multicolumn{5}{|c|}{$\begin{array}{l}\text { Nature of respondent's investment } \\
\text { activity }\end{array}$} \\
\hline Buy side & 404 & 56.5 & 218 & 54.8 \\
\hline Sell side & 262 & 36.6 & 161 & 40.5 \\
\hline \multirow[t]{2}{*}{ Other } & 49 & 6.9 & 19 & 4.8 \\
\hline & $\overline{715}$ & $\overline{100.0}$ & 398 & 100.0 \\
\hline
\end{tabular}


TABLE 2. Continued

\begin{tabular}{|c|c|c|c|c|}
\hline \multirow[b]{2}{*}{ Attribute } & \multicolumn{2}{|c|}{ International } & \multicolumn{2}{|c|}{ North American } \\
\hline & Number & Percent & Number & Percent \\
\hline \multicolumn{5}{|l|}{ Employer" } \\
\hline Broker or investment bank & 278 & 38.8 & 154 & 38.6 \\
\hline $\begin{array}{l}\text { mutual fund } \\
\text { Investment counseling and }\end{array}$ & 131 & 18.3 & 33 & 8.3 \\
\hline money management & 121 & 16.9 & 99 & 24.8 \\
\hline Insurance company & 39 & 5.4 & 39 & 9.8 \\
\hline Commercial bank & 78 & 10.9 & 45 & 11.3 \\
\hline Other & $\frac{69}{716}$ & $\frac{9.6}{100.0}$ & $\frac{29}{399}$ & $\frac{7.3}{100.0}$ \\
\hline \multicolumn{5}{|l|}{$\begin{array}{l}\text { Number of analysts and portfolio } \\
\text { managers employed by the } \\
\text { respondent's firm }\end{array}$} \\
\hline Less than 10 & 256 & 35.9 & 143 & 36.3 \\
\hline 10 to 19 & 137 & 19.2 & 91 & 23.1 \\
\hline 20 to 29 & 53 & 7.4 & 48 & 12.2 \\
\hline 30 to 39 & 27 & 3.8 & 24 & 6.1 \\
\hline \multirow[t]{2}{*}{40 or more } & $\underline{241}$ & 33.8 & 88 & 22.3 \\
\hline & $\overline{714}$ & 100.0 & $\overline{394}$ & $\overline{100.0}$ \\
\hline
\end{tabular}

Note: The percentages may not add to 100 because of rounding.

$\mathrm{NA}=$ not asked in the survey.

${ }^{3}$ The distributions of responses differ significantly between the international and North American surveys based on chi-square tests.

\section{transactions.}

- The most common employer group is a brokerage or investment bank.

- Firms having fewer than 10 analysts and portfolio managers employ more than one-third of the respondents, and firms with 40 or more analysts and portfolio managers employ another third.

A comparison of attributes of the international respondents and the North American respondents revealed both similarities and differences. The chisquare tests show that the attributes are similar for gender and for nature of the respondent's investment activity but differ significantly on all other attributes shown in Table 2. For example, the chi-square tests show that the respondents in the international survey are significantly younger, have less experience in the investment business, are less well educated, and among them hold fewer CFA charters than do respondents in the North American survey. The type of employer and number of analysts and portfolio managers of the respondent's firm also differ significantly between the two surveys.

Differences in respondent characteristics between the two populations could 
account for some dissimilar responses that will be discussed later. Nonetheless, the characteristics of both studies are representative of their respective groups. On balance, the distribution of the AIMR member population as to age and experience is more even in North America than outside the continent. In addition, 70 percent of the respondents in North America had already earned their CFA designations versus almost 76 percent outside North America who are still CFA candidates; this finding attests to the dramatic growth of AIMR internationally.

\section{Professional Comparisons}

One objective of the study was to discover how investment professionals view their ethical behavior as compared with their perceptions about five other professional groups: lawyers, commercial bankers, corporate managers, politicians, and engineers. For each profession, respondents were asked to give their perceptions of actual ethical behavior on a four-point scale, in which $1=$ not ethical, $2=$ somewhat ethical, $3=$ moderately ethical, and $4=$ highly ethical.

Table 3 presents perceptions about ethical behavior of the six professions. In the international survey, investment professionals gave their profession a weighted-average rating of 2.70 , which falls between "somewhat ethical" and "moderately ethical." Only 3.5 percent of the respondents perceive that investment professionals are "not ethical"; 7.3 percent believe investment professionals are "highly ethical." The ranking for investment professionals falls below both engineers and commercial bankers but above lawyers, corporate managers, and politicians. Politicians are the only group to receive a rating falling between "not ethical" and "somewhat ethical." Chi-square tests show that the responses for each professional group differ significantly from responses for each other professional group.

Table 3 also shows similar rankings between the international and North American surveys on the perceived ethical behavior of various professions. The Spearman rank correlation coefficient of 0.89 confirms a statistically significant association between the rankings. Investment professionals rank third and second in the international and North American surveys, respectively. In both surveys, the respondents reported believing that engineers exhibit the highest level of ethical behavior and politicians the lowest. Chisquare tests, however, show that the distributions of responses between the international and North American surveys differ significantly for each profession.

Table 4 reports the responses on a country basis. The respondents ranked investment professionals anywhere from second to fourth among the six 


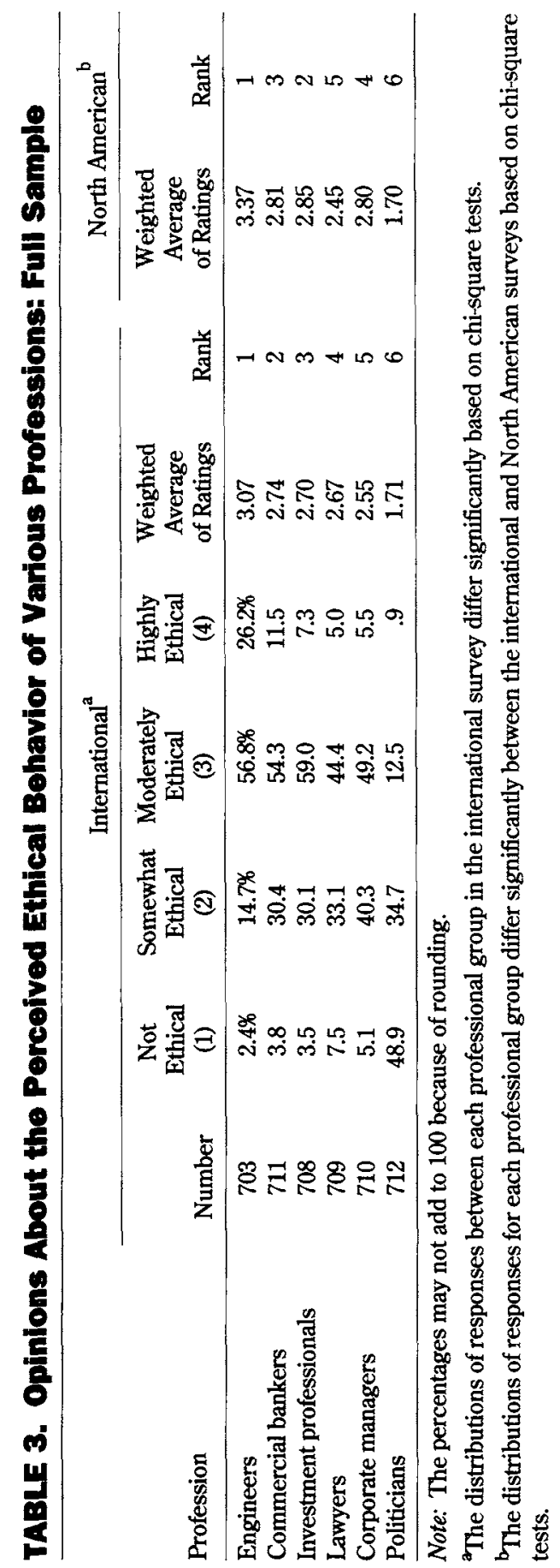




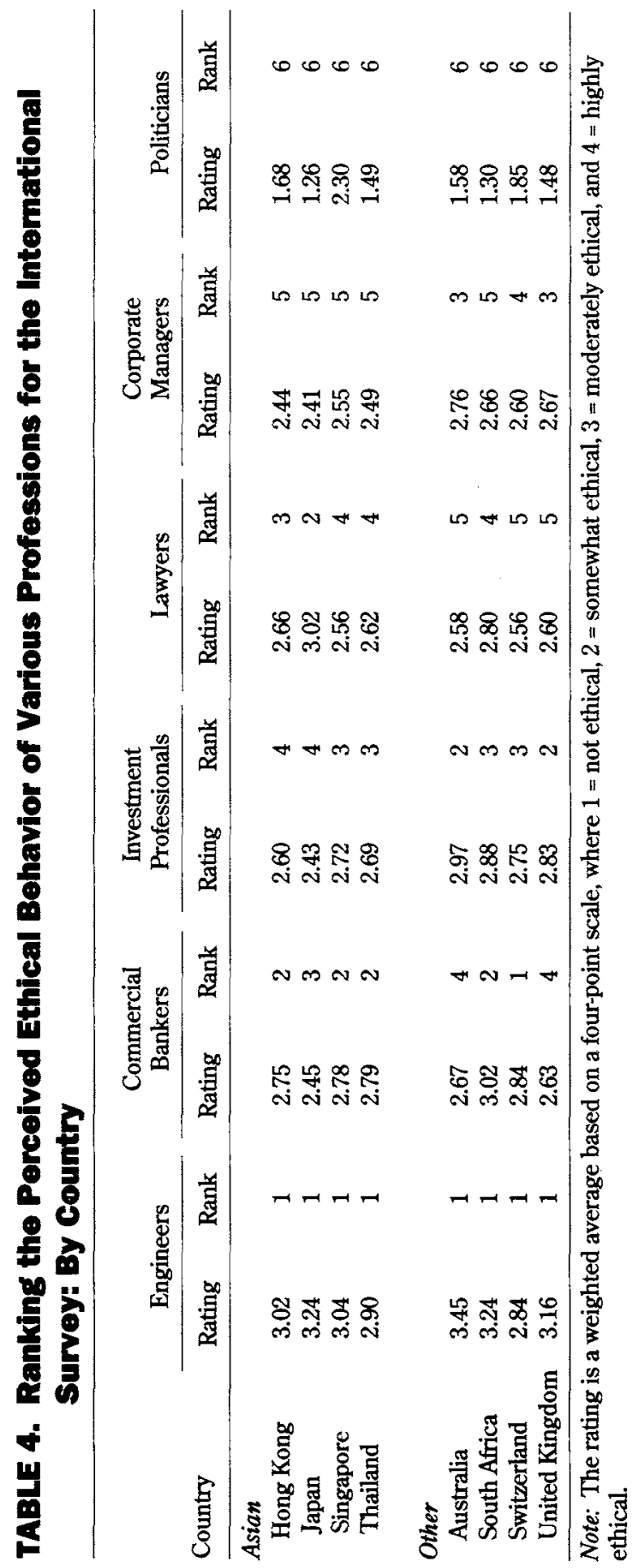


professions. At the same time, the respondents from each country consistently perceive engineers as exhibiting the highest level and politicians the lowest level of ethical behavior. These results suggest that the low esteem in which politicians are held is a global phenomenon.

\section{Ethical Trends}

The international survey also examined the perceptions of respondents about past and future ethical standards of investment professionals. As Table 5 shows, more than 65 percent of the respondents believe that ethical standards of investment professionals in their countries have improved during the past ten years. About 20 percent said that ethical standards have not changed, and about 6 percent thought that standards have deteriorated. More than two-thirds of the respondents expect future ethical standards of investment professionals to improve, another 12.3 percent expect standards to remain unchanged, and only 6.4 percent expect ethical standards to deteriorate.

Chi-square tests show that the results of the international survey differ significantly from those of the North American survey on the issues of past and future ethical standards of investment professionals. As Table 5 shows, a

\section{TABLE 5. Percelved Trends In Ethlcal Standards of Investment} Professionals

\begin{tabular}{|c|c|c|c|c|}
\hline \multirow[b]{2}{*}{ Trend } & \multicolumn{2}{|c|}{ International } & \multicolumn{2}{|c|}{ North American } \\
\hline & Number & Percent & Number & Percent \\
\hline \multicolumn{5}{|c|}{$\begin{array}{l}\text { During the past ten years, ethical } \\
\text { standards of investment professionals } \\
\text { in your country }\end{array}$} \\
\hline Improved & 471 & $65.8 \%$ & 96 & $24.3 \%$ \\
\hline Remained unchanged & 145 & 20.3 & 109 & 27.6 \\
\hline Deteriorated & 46 & 6.4 & 138 & 34.9 \\
\hline No opinion & $\frac{54}{716}$ & $\frac{7.5}{100.0}$ & $\frac{52}{395}$ & $\frac{13.2}{100.0}$ \\
\hline \multicolumn{5}{|c|}{$\begin{array}{l}\text { During the next ten years, ethical } \\
\text { standards of investment professionals } \\
\text { in your country are likely to }{ }^{\mathrm{a}}\end{array}$} \\
\hline Improve & 559 & 78.1 & 247 & 63.0 \\
\hline Remain unchanged & 88 & 12.3 & 108 & 27.6 \\
\hline Deteriorate & 46 & 6.4 & 21 & 5.4 \\
\hline \multirow{2}{*}{ No opinion } & 23 & 3.2 & 16 & 4.1 \\
\hline & $\overline{716}$ & $\overline{100.0}$ & $\overline{392}$ & $\overline{100.0}$ \\
\hline
\end{tabular}

Note: The percentages may not add to 100 because of rounding.

The responses of the international participants differ significantly from those of the North American participants. 
much larger percentage of the international respondents than of their North American counterparts believe ethical standards in the investment profession have improved. This difference may reflect the timing of the studies. The North American study was conducted in 1990 and may reflect the views of the respondents about several highly publicized cases of insider trading that occurred in the United States in the late 1980s. This difference may also reflect the population differences mentioned earlier. Almost half the respondents surveyed in North America had been in the industry ten years before the survey was conducted, compared with about 15 percent in the international survey. Another possible explanation is that ethical standards improved and AIMR membership increased as some of these markets developed and international participation increased. In any event, the international study is not only more current but also covers more countries than the North American survey.

Both studies show that most respondents believe that ethical standards in the investment profession are likely to improve, but the international respondents are more positive about this improvement than were their North American counterparts. Again, this finding may reflect a sample bias.

Table 6 presents the responses about past and future ethical standards of investment professionals by each country represented in the international survey. The percentage of respondents believing that ethical standards of investment professionals have improved in their country during the past ten years ranges from almost 80 percent in Switzerland to about 41 percent in South Africa.

In seven of the eight countries, the number of respondents who expect ethical standards of investment professionals in their countries to improve during the next ten years exceeds the number who perceive standards to have improved in the past ten years. In Hong Kong, however, the percentage of respondents expecting ethical standards to improve during the next ten years is slightly less than the percentage of those saying that such standards have improved during the past ten years (67.7 percent versus 68.5 percent, respectively). Among the eight countries surveyed, respondents from Japan and South Africa expect the most relative improvement in ethical standards between the two ten-year periods. Despite that finding for South Africa, more than 29 percent of the respondents from South Africa expect ethical standards to deteriorate in that country during the next ten years.

\section{Learning about Ethics}

To find out how people learn ethical behavior, respondents were asked to indicate how much of an investment professional's training and education 


\section{TABLE 6. Percelved Trends in Ethical Standards of Investment Professlonals for the Intemational Survey Only: By Country}

\begin{tabular}{|c|c|c|c|c|c|}
\hline Country & Number & Improve(d) & Deteriorate(d) & $\begin{array}{l}\text { Remain(ed) } \\
\text { Unchanged }\end{array}$ & No Opinion \\
\hline \multicolumn{6}{|c|}{$\begin{array}{l}\text { Trends in the ethical standards } \\
\text { of investment professionals } \\
\text { during the past ten years } \\
\text { Asian }\end{array}$} \\
\hline Hong Kong & 130 & $68.5 \%$ & $4.6 \%$ & $17.7 \%$ & $9.2 \%$ \\
\hline Japan & 95 & 53.7 & 4.2 & 33.7 & 8.4 \\
\hline Singapore & 149 & 64.4 & 4.0 & 19.5 & 12.1 \\
\hline Thailand & 39 & 74.4 & 7.7 & 14.4 & 2.6 \\
\hline \multicolumn{6}{|l|}{ Other } \\
\hline Australia & 32 & 65.6 & 3.1 & 18.8 & 12.5 \\
\hline South Africa & 51 & 41.2 & 29.4 & 27.5 & 2.0 \\
\hline Switzerland & 128 & 79.7 & 1.6 & 17.2 & 1.6 \\
\hline United Kingdom & 92 & 67.4 & 9.8 & 14.1 & 8.7 \\
\hline Total & $\overline{716}$ & & & & \\
\hline \multirow{2}{*}{\multicolumn{6}{|c|}{$\begin{array}{l}\text { Expected trends in the ethical } \\
\text { standards of investment } \\
\text { professionals during the next } \\
\text { ten years } \\
\text { Asian }\end{array}$}} \\
\hline & & & & & \\
\hline Hong Kong & 130 & 67.7 & 11.5 & 15.4 & 5.4 \\
\hline Japan & 95 & 83.2 & 1.1 & 13.7 & 2.1 \\
\hline Singapore & 149 & 79.2 & 6.7 & 8.7 & 5.4 \\
\hline Thailand & 39 & 89.7 & 2.6 & 5.1 & 2.6 \\
\hline \multicolumn{6}{|l|}{ Other } \\
\hline Australia & 33 & 72.7 & 0.0 & 21.2 & 6.1 \\
\hline South Africa & 51 & 60.8 & 29.4 & 9.8 & 0.0 \\
\hline Switzerland & 127 & 87.4 & 0.8 & 11.8 & 0.0 \\
\hline United Kingdom & $\frac{92}{716}$ & 79.3 & 3.3 & 14.1 & 3.3 \\
\hline Total & $\overline{716}$ & & & & \\
\hline
\end{tabular}

Note: The percentages may not add to 100 because of rounding.

about ethical behavior should come from various sources. Respondents gave their views on this issue using a four-point scale, in which $1=$ none, $2=$ small amount, $3=$ moderate amount, and $4=$ large amount. As Table 7 shows, more than half the respondents believe that a "large amount" of an investment professional's training in ethical behavior should come from four sources: senior management, the employing firm, professional organizations, and the home environment. Based on the weighted-average ratings, the respondents clearly view the example set by senior management as the single most impor- 


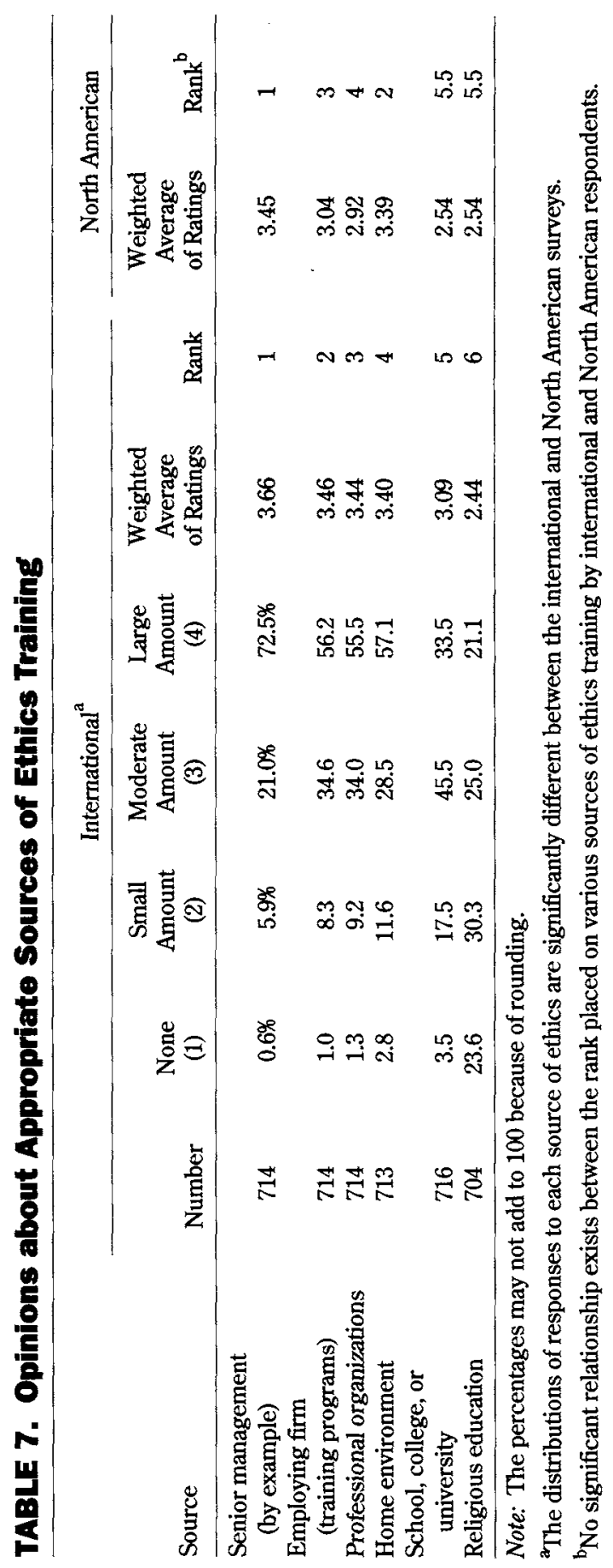


tant source of ethical training and education. The two lowest ranking sources are school, college, or university and religious education. Chi-square tests show that the responses differ significantly between each source and the other sources except between the employing firm and professional organizations.

Table 7 also presents the rankings of the six sources of ethics training, based on their weighted-average ratings, for the international and North American surveys. A Spearman rank correlation coefficient of 0.81 shows no significant association between the rankings of the two groups. Although most rankings differ, a firm's senior management and religious education rank first and last, respectively, in both surveys as appropriate sources of an investment professional's training and education in ethical behavior. Chi-square tests show that the distributions of responses for each source in the international survey differ significantly from the distributions for corresponding sources in the North American survey.

Table 8 reports the respondents' views by country about how much of an investment professional's training and education in ethical behavior should come from each source. The rankings are consistent at the extremes. Senior management ranks as the primary source of an investment professional's training and education; school, college, or university ranks fifth; and religious education ranks sixth.

Table 9 contains the respondents' opinions about how effective the six sources have been in providing useful training and education in ethical behavior. Respondents gave their views on this issue using a four-point scale, in which 1 = not effective, 2 = slightly effective, $3=$ moderately effective, and $4=$ highly effective.

In the international study, investment professionals gave home environment the highest weighted-average rating, 3.38, which falls between "moderately effective" and "highly effective." Almost 58 percent of the respondents believe that their home environment has been highly effective. The remaining sources of useful training and education in ethical behavior are, in declining order of effectiveness, professional organizations; senior management (by example); employing firm (training programs); school, college, or university; and religious education. Chi-square tests show that the responses for each source differ significantly from those for the other sources.

A comparison of the responses from the international and North American surveys shows no significant association between the rankings of the sources based on the Spearman rank correlation coefficient of 0.75 . Nevertheless, the respondents to both surveys rank home environment first as providing useful training and education in ethical behavior.

Table 10 provides a country breakdown of the perceived effectiveness of the 


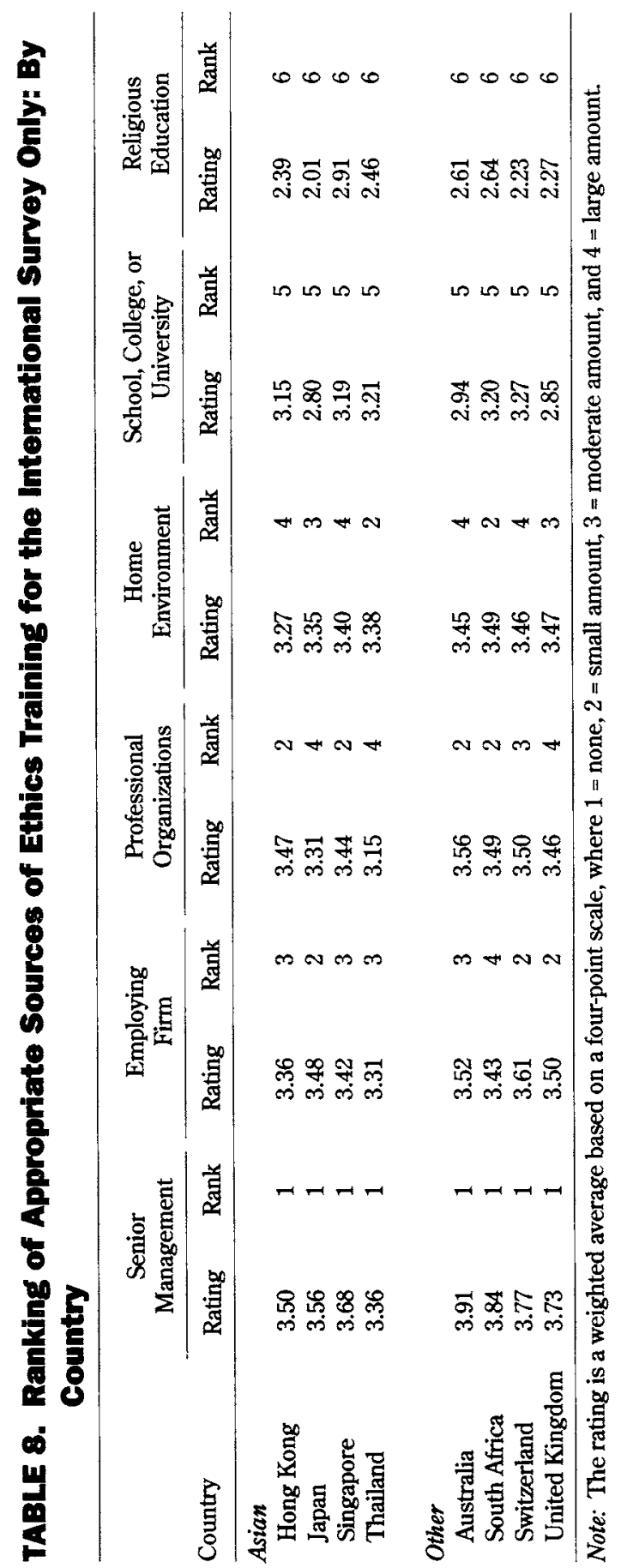




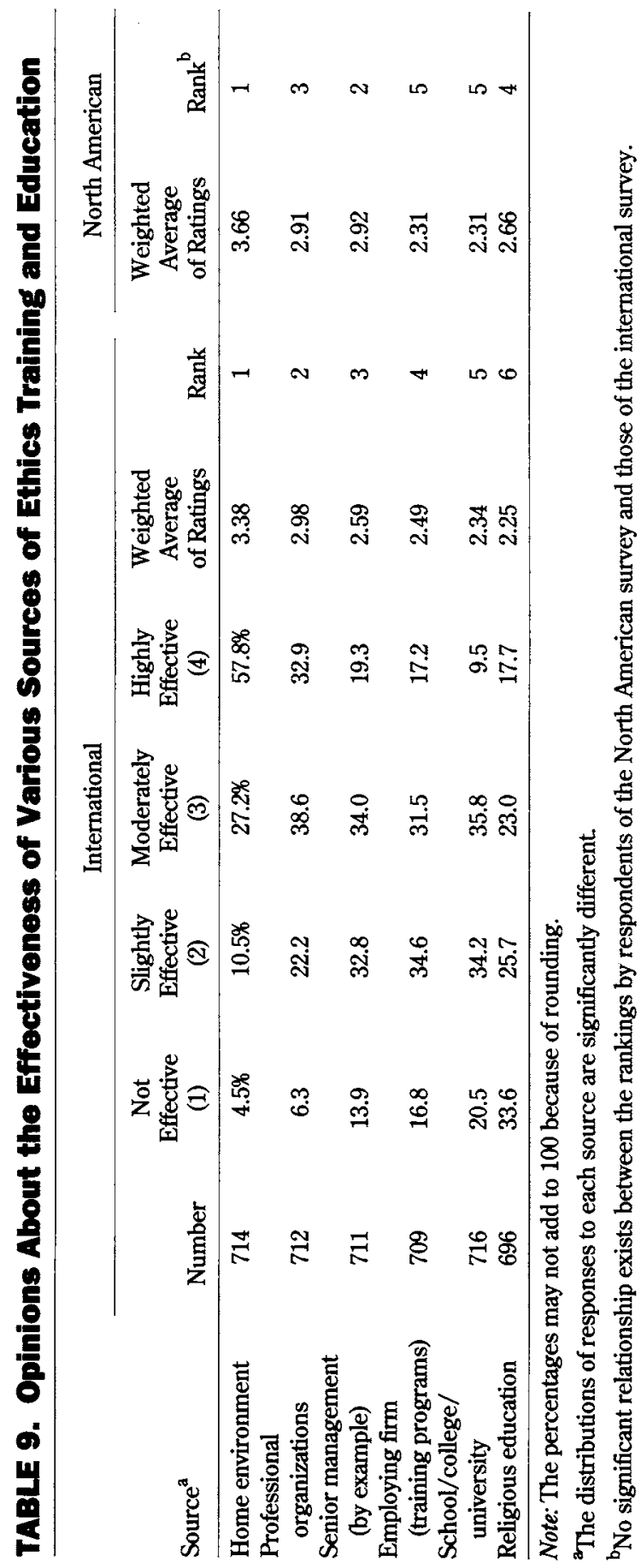




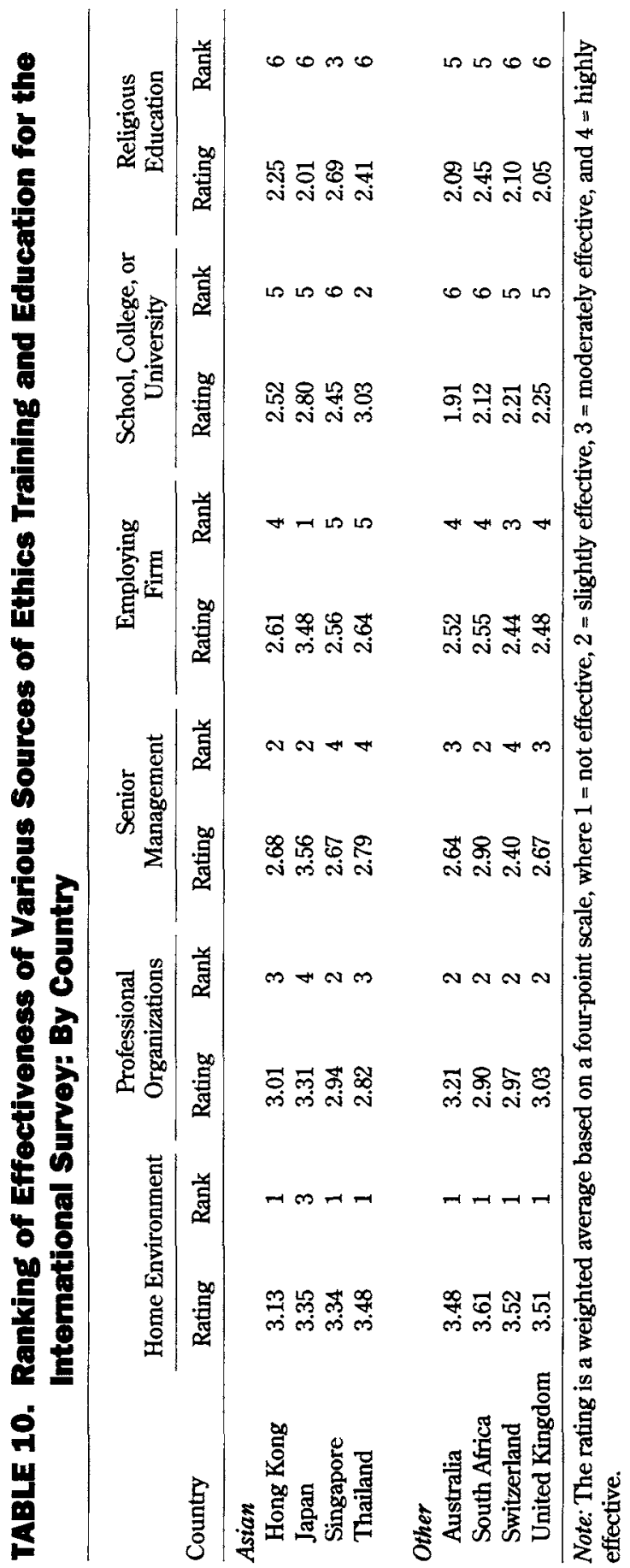


six sources of ethical training and education. The rankings are similar at the extremes, with some notable exceptions, but show variability for the midranked sources. For example, home environment ranks first in effectiveness except by the respondents from Japan, who view the employing firm as the most effective source of ethics training and education. Religious education ranks fifth or sixth in effectiveness except among the respondents from Singapore, who rank this source third.

The respondents differed in their views about how much of an investment professional's training and education in ethical behavior should come from a certain source and how effective the source is. Table 11 shows the difference between the weighted-average rating for each source appearing in Tables 7 and 9.

For the international survey, the results suggest that respondents believe all six sources are less effective than they should be. The largest gap among the sources occurs for senior management, followed by the employing firm and then school, college, or university. For the North American survey, the gap is smaller for these three sources than in the international survey, but both surveys suggest that opportunities exist for senior management, employing firms, and schools, colleges, or universities to improve their ethics training and education for investment professionals.

\section{Deterrents to Unethical Behavior}

Many factors may deter people from behaving unethically. Survey participants were asked to give their opinions about the importance of six deterrents using a four-point scale, in which 1 = not important, 2 = slightly important, $3=$ moderately important, and $4=$ highly important.

\section{TABLE 11. Appropriate Sources of Ethical Education Compared with the Effectiveness of Those Sources}

\begin{tabular}{lcc}
\hline & \multicolumn{2}{c}{ Difference in Weighted-Average Rating } \\
\cline { 2 - 3 } Source & International & North American \\
\hline Senior management (by example) & -1.07 & -0.53 \\
Employing firm (training programs) & -0.97 & -0.73 \\
School, college, or university & -0.75 & -0.23 \\
Professional organizations & -0.46 & -0.01 \\
Formal religious education & -0.19 & +0.12 \\
Home environment & -0.02 & +0.27 \\
\hline
\end{tabular}

${ }^{\mathrm{a} A \text { minus sign shows the source has been a less effective source of training and education than respondents }}$ think it should be; a plus sign shows the source has been a more effective source than respondents think it should be. 
Table 12 shows the most highly ranked deterrent to unethical behavior for the international respondents to be concern about disciplinary action by the professional's employer. More than 88 percent of the respondents believe this deterrent is either "moderately important" or "highly important." The next most important deterrent to unethical behavior is concern about sanctions from government agencies. Concern about sanctions from self-regulatory organizations ranks third, followed by moral or religious beliefs, having a published code of ethics, and concern that family or friends will find out. The chi-square tests show that the six deterrents differ significantly from one another.

Table 12 also shows the responses about deterrents to unethical behavior from the North American survey. The results are not fully comparable with those of the international survey because the North American survey excluded the deterrent concerning disciplinary action by the professional's employer. The most important deterrent to unethical behavior in the North American survey is sanctions from government agencies. Having a published code of ethics ranks as the least important deterrent.

The chi-square tests between the respondents of the international and North American surveys show that the distributions of responses differ significantly on all five deterrents. As a group, the international respondents view concern about sanctions from self-regulatory organizations and having a published code of ethics as more important deterrents than do the North American respondents. Conversely, the North American respondents view moral or religious beliefs and concern that family or friends will find out as greater deterrents than do the international respondents.

Table 13 presents the rankings of the six deterrents to unethical behavior for each country surveyed. The rankings of the deterrents are similar at the extremes. Respondents from all eight countries rank concern about disciplinary action by the professional's employer as either the first or second most important deterrent to unethical behavior. Respondents from half the countries surveyed rank the concern that family or friends will find out as the least important deterrent. Only in South Africa did this deterrent rank among the three most important deterrents.

\section{Framework for Ethical Behavior}

To learn more about ethical practices within the survey participants' firms, participants were asked several questions in order to ascertain whether the firms have their own codes of ethics and, if so, require investment professionals to read them. As Table 14 shows, slightly more than 40 percent of the 


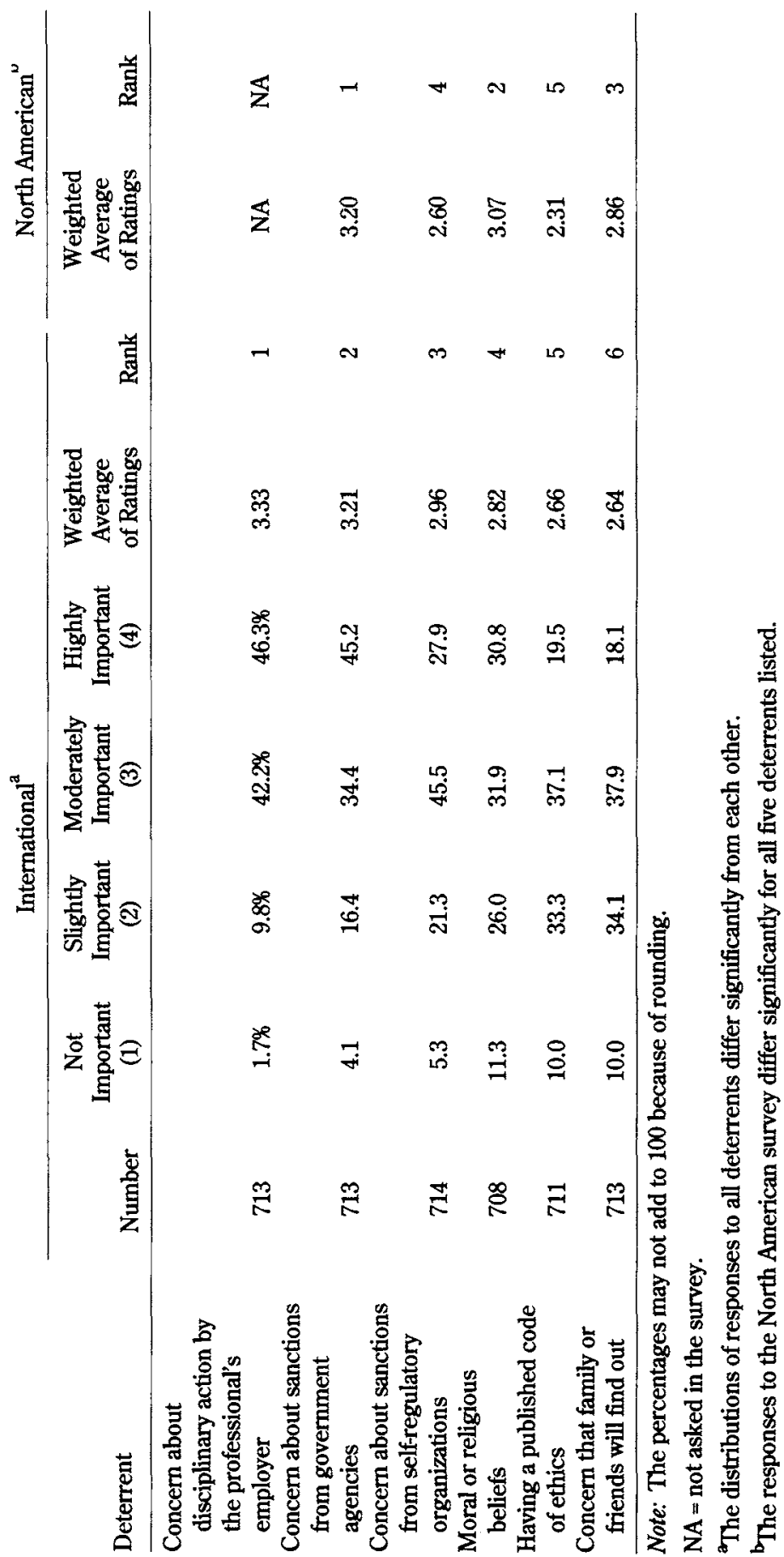




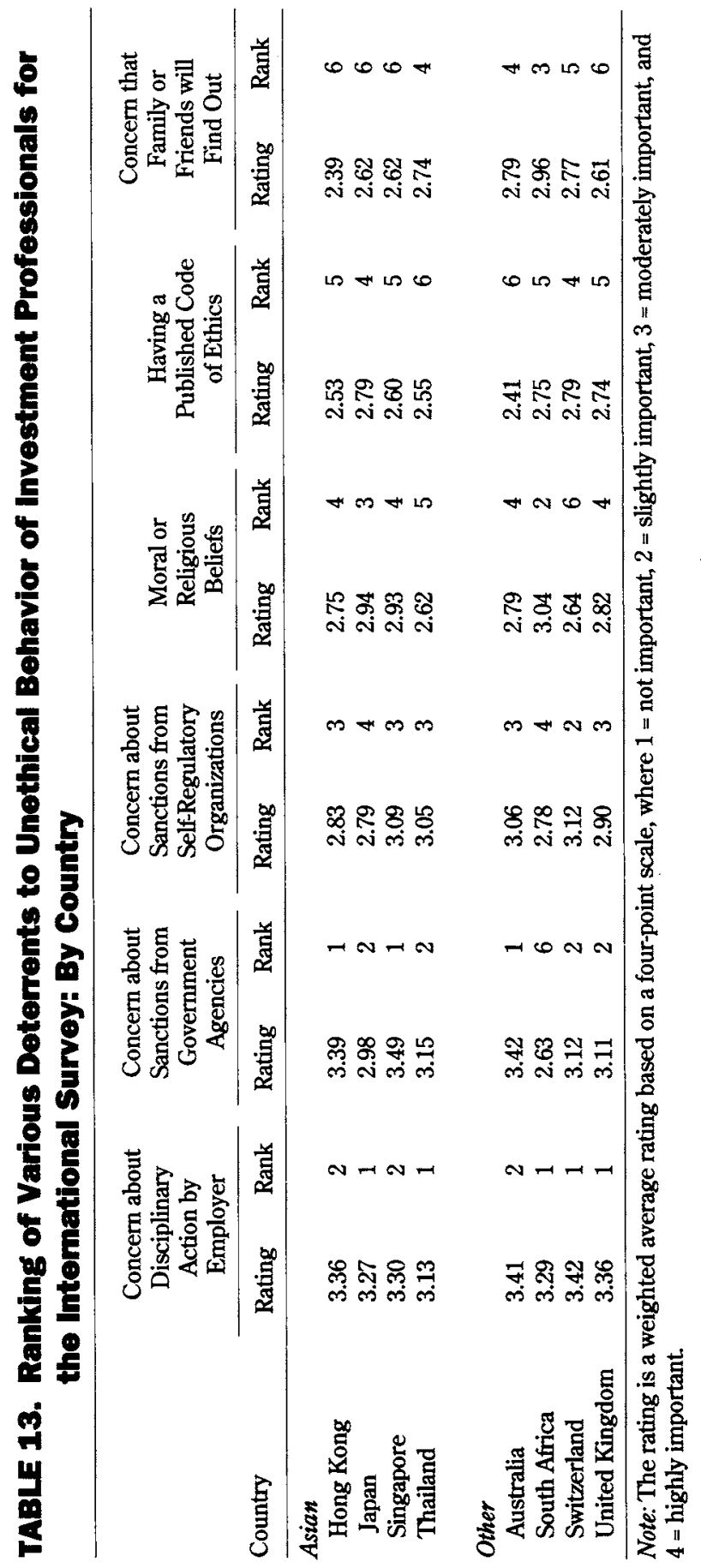


TABLE 14. Employers' Codes of Ethics

\begin{tabular}{|c|c|c|c|c|}
\hline \multirow[b]{2}{*}{ Trend } & \multicolumn{2}{|c|}{ International } & \multicolumn{2}{|c|}{ North American } \\
\hline & Number & Percent $^{a}$ & Number & Percent $^{\mathrm{a}}$ \\
\hline \multicolumn{5}{|c|}{$\begin{array}{l}\text { Does your firm publish its own } \\
\text { code of ethics separately from that } \\
\text { of any professional organization's } \\
\text { code of ethics? }\end{array}$} \\
\hline Yes & 291 & $40.6 \%$ & 206 & $51.6 \%$ \\
\hline No & 370 & 51.7 & 193 & 48.4 \\
\hline Don't know & 55 & 7.7 & NA & $\mathrm{NA}$ \\
\hline Total & $\overline{716}$ & 100.0 & $\frac{127}{399}$ & $\frac{1.1}{100.0}$ \\
\hline \multicolumn{5}{|c|}{$\begin{array}{l}\text { If your firm endorses a code of ethics } \\
\text { (either its own or that of a professional } \\
\text { organization), does it require its investment } \\
\text { professionals to read the code of ethics? }\end{array}$} \\
\hline Yes & 321 & 45.3 & 202 & 58.9 \\
\hline No & 163 & 23.0 & 141. & 41.1 \\
\hline Don't know & 69 & 9.7 & NA & $\mathrm{NA}$ \\
\hline Not applicable & $\underline{155}$ & 21.9 & $\underline{\mathrm{NA}}$ & NA \\
\hline Total & $\overline{708}$ & 100.0 & 343 & $\overline{100.0}$ \\
\hline \multicolumn{5}{|c|}{$\begin{array}{l}\text { If yes, how frequently does your firm require } \\
\text { investment professionals to read the code of } \\
\text { ethics it endorses? }\end{array}$} \\
\hline $\begin{array}{l}\text { One time only when } \\
\text { employment begins }\end{array}$ & 178 & 55.6 & 29 & 14.7 \\
\hline Once each year & 82 & 25.6 & 151 & 76.6 \\
\hline Once every two years & 9 & 2.8 & 5 & 2.5 \\
\hline Other & 51 & 15.9 & 12 & 6.1 \\
\hline Total & 320 & 100.0 & $\overline{197}$ & $\overline{100.0}$ \\
\hline \multicolumn{5}{|c|}{$\begin{array}{l}\text { If yes, are the investment professionals } \\
\text { in your firm required to provide written } \\
\text { verification that they have read and will } \\
\text { comply with the code of ethics it endorses? }\end{array}$} \\
\hline Yes & 201 & 61.8 & 165 & 82.5 \\
\hline No & 115 & 35.4 & 35 & 17.5 \\
\hline Don't know & 9 & 2.8 & $\mathrm{NA}$ & NA \\
\hline Total & $\overline{325}$ & $\overline{100.0}$ & 200 & $\overline{100.0}$ \\
\hline
\end{tabular}

$\mathrm{NA}=$ not asked in the survey.

${ }^{2}$ The percentages may not add to 100 because of rounding.

${ }^{b}$ The responses to this question in the international survey differ significantly from those in the North American survey.

international respondents reported that their firms publish a code of ethics separately from that of any professional organization. Of those firms endorsing a code of ethics, either their own or that of a professional organization, about 
45 percent require investment professionals to read the code.

Those survey participants required to read a code of ethics were also asked how often they must do so. About 56 percent report that they must read the code of ethics one time only, when employment begins. More than a quarter report that employers require them to read the code once a year. About 62 percent of participants required to read a code of ethics must provide written verification that they have read and will follow the code.

Based on chi-square tests, the responses to each question shown in Table 14 differ significantly between the international and North American surveys. Far fewer international firms than North American firms publish their own codes of ethics and require investment professionals to read the codes they endorse. For those North American firms requiring investment professionals to read the firm's code of ethics, a much larger percentage than in the international group also require them to read the code once a year and to provide written verification that they have read and will follow the code.

Table 15 presents the percentage of firms publishing a code of ethics and requiring their investment professionals to read a code of ethics, either their own or that of a professional organization, for each country surveyed. The percentage of firms publishing a code of ethics ranges from 23.5 percent in South Africa to 64.1 percent in the United Kingdom. The percentage of firms requiring their investment professionals to read the code of ethics endorsed by the firm also varies widely, ranging from 30.0 percent in South Africa to 71.7 percent in the United Kingdom.

\section{TABLE 15. Employers' Codes of Ethics for the International Survey: By Country}

\begin{tabular}{lcc}
\hline & $\begin{array}{c}\text { Percent of Firms Endorsing } \\
\text { Percent of Firms Publishing } \\
\text { Their Own Code of Ethics }\end{array}$ & $\begin{array}{c}\text { Investment Professionals to } \\
\text { Read the Code of Ethics }\end{array}$ \\
\hline Asian & & \\
$\quad$ Hong Kong & $42.6 \%$ & $45.7 \%$ \\
Japan & 49.5 & 43.6 \\
Singapore & 37.6 & 42.3 \\
Thailand & 33.3 & 36.8 \\
& & \\
Other & 54.5 & 54.5 \\
Australia & 23.5 & 30.0 \\
South Africa & 24.2 & 36.6 \\
$\quad$ Switzerland & 64.1 & 71.7 \\
United Kingdom & & \\
\hline
\end{tabular}


The eight countries were ranked based on two variables-the percentage of firms in each country publishing a code of ethics and the percentage of firms in each country requiring their investment professionals to read the code of ethics endorsed by the firm. A Spearman rank correlation coefficient of 0.98 shows a significant association between these two variables. That is, firms that publish their own codes of ethics typically require their investment professionals to read the codes.

Three questions were asked about the presence of officers within respondent firms whose duties are to ensure compliance with legal and ethical standards. As Table 16 shows, about half the respondents in the international survey reported that their firms have a compliance officer. Of those respondents, more than 80 percent know the name of this officer. In a related question, survey participants were asked to indicate the position of the firm's compliance officer. The most often cited position of the compliance officer is director (27.6 percent), followed by vice president (19.4 percent), and executive or senior vice president (18.1 percent).

Chi-square tests show differences between the responses from the international and North American surveys concerning compliance officers. Specifically, a significantly smaller percentage of respondents from the international survey than from the North American survey reported that their firms have a compliance officer (49.2 percent versus 75.3 percent, respectively). The positions of the compliance officer also differ significantly between the two surveys. For example, the most common position of the compliance officer in the international survey is director (27.6 percent), whereas vice president (43.5 percent) is the most common position in the North American survey. The percentages of respondents who know the name of their firm's compliance officer, however, are similar in the two groups of respondents.

As Table 17 shows, the percentage of firms with a compliance officer varies widely among the eight countries. Less than 30 percent of the respondents from Thailand and Switzerland but more than 90 percent in the United Kingdom reported that their firms have a compliance officer. The eight countries are ranked according to three variables: the percentage of firms with a compliance officer, the percentage of firms that publish a code of ethics, and the percentage of firms that require investment professionals to read a code of ethics. The analysis shows a significantly positive correlation between the percentage of firms in each country with a compliance officer and the other two variables. In both relationships, the Spearman rank correlation coefficient is 0.88 . Thus, firms with a compliance officer typically publish a code of ethics and require their investment professionals to read a code of ethics. 
Survey Results

TABLE 16. Compliance Officers

\begin{tabular}{|c|c|c|c|c|}
\hline \multirow[b]{2}{*}{ Question } & \multicolumn{2}{|c|}{ International } & \multicolumn{2}{|c|}{ North American } \\
\hline & Number & Percent ${ }^{a}$ & Number & Percent $^{a}$ \\
\hline \multicolumn{5}{|l|}{$\begin{array}{l}\text { Does your firm have a compliance } \\
\text { officer to ensure legal and ethical } \\
\text { standards are maintained? }\end{array}$} \\
\hline Yes & 352 & $49.2 \%$ & 298 & $75.3 \%$ \\
\hline No & 284 & 39.7 & 98 & 24.7 \\
\hline Don't know & 80 & 11.2 & NA & $\mathrm{NA}$ \\
\hline Total & $\widetilde{716}$ & 100.0 & 396 & 100.0 \\
\hline \multicolumn{5}{|l|}{$\begin{array}{l}\text { If yes, do you know the name of your } \\
\text { firm's compliance officer? }\end{array}$} \\
\hline Yes & 293 & 81.2 & 256 & 85.9 \\
\hline No & 68 & 18.8 & 42 & 14.1 \\
\hline Total & 361 & 100.0 & 298 & 100.0 \\
\hline \multicolumn{5}{|l|}{$\begin{array}{l}\text { If yes, what is the position of your firm's } \\
\text { compliance officer? }\end{array}$} \\
\hline Chairs the board of directors & 1 & 0.3 & 6 & 2.4 \\
\hline Director & 84 & 27.6 & 16 & 6.3 \\
\hline President & 23 & 7.6 & 13 & 5.1 \\
\hline Executive or senior vice president & 55 & 18.1 & 89 & 34.9 \\
\hline Vice president & 59 & 19.4 & 111 & 43.5 \\
\hline Below the vice president level & 31 & 10.2 & 20 & 7.8 \\
\hline Other & 39 & 12.8 & NA & NA \\
\hline Don't know & 12 & 3.9 & $\underline{N A}$ & NA \\
\hline Total & $\overline{304}$ & $\overline{100.0}$ & 255 & $\overline{100.0}$ \\
\hline
\end{tabular}

$\mathrm{NA}=$ not asked in the survey.

The percentages may not add to 100 because of rounding.

b، The distributions of responses to the question differ significantly between the international survey and the North American survey."

"The survey used different but roughly equivalent names to describe the positions of compliance officers in various countries. For "director," the term "managing director" was used in Japan. For "president," the term "managing director" was used in South Africa and "officer" was used in the United Kingdom. For "executive" or "senior vice president," the term "department head" was used in Japan, "executive" or "senior director" was used in South Africa, and "senior manager" was used in the United Kingdom. For "vice president," the term "section chief" was used in Japan, "management" was used in South Africa, and "below senior manager" was used in the United Kingdom. For "below the vice president" level, the term "below section chief" was used in Japan and "below management level" was used in South Africa.

\section{Nature and Frequency of Ethics Violations}

An important issue in this study is the extent to which ethical violations occur in the investment profession. The survey participants were thus asked to indicate the frequency often types of ethical or legal violations based on their personal experience or observation. Each respondent was asked to state how frequently the violation occurs on a four-point scale, in which $1=$ never, $2=$ 


TABLE 17. Compliance Officers for the Intermational Survey: By
Country

seldom, $3=$ sometimes, and $4=$ often.

As Table 18 shows, at least 50 percent of the international respondents reported that four of the ten violations occur "sometimes" or "often." The two most frequently cited violations involve inside information-either trading based on inside information or communicating inside information. The two other most frequently cited violations are the failure to use diligence and thoroughness in making recommendations and writing reports that support predetermined conclusions.

The fifth and sixth most frequent violations relate to dealings with clients. More than 46 percent of the respondents reported that failure to disclose conflicts of interest to clients and not dealing fairly with all clients when taking investment action occur "sometimes" or "often."

The ethical violation ranked seventh is plagiarizing another's work. More than 42 percent of the respondents reported experiencing or observing plagiarism in the investment profession. The eighth most common ethics violation is front running (making personal trades before client trades). Almost 46 percent reported experiencing or observing front running either "sometimes" or "often."

The least common ethics violations listed in Table 18 are failure to disclose conflicts of interest to the professional's employer and misrepresenting a firm's past or expected future performance. Although least common, these violations were reported by more than 36 percent of the respondents as occurring "sometimes" or "often."

A test of the rankings of the ten violations between the international and 


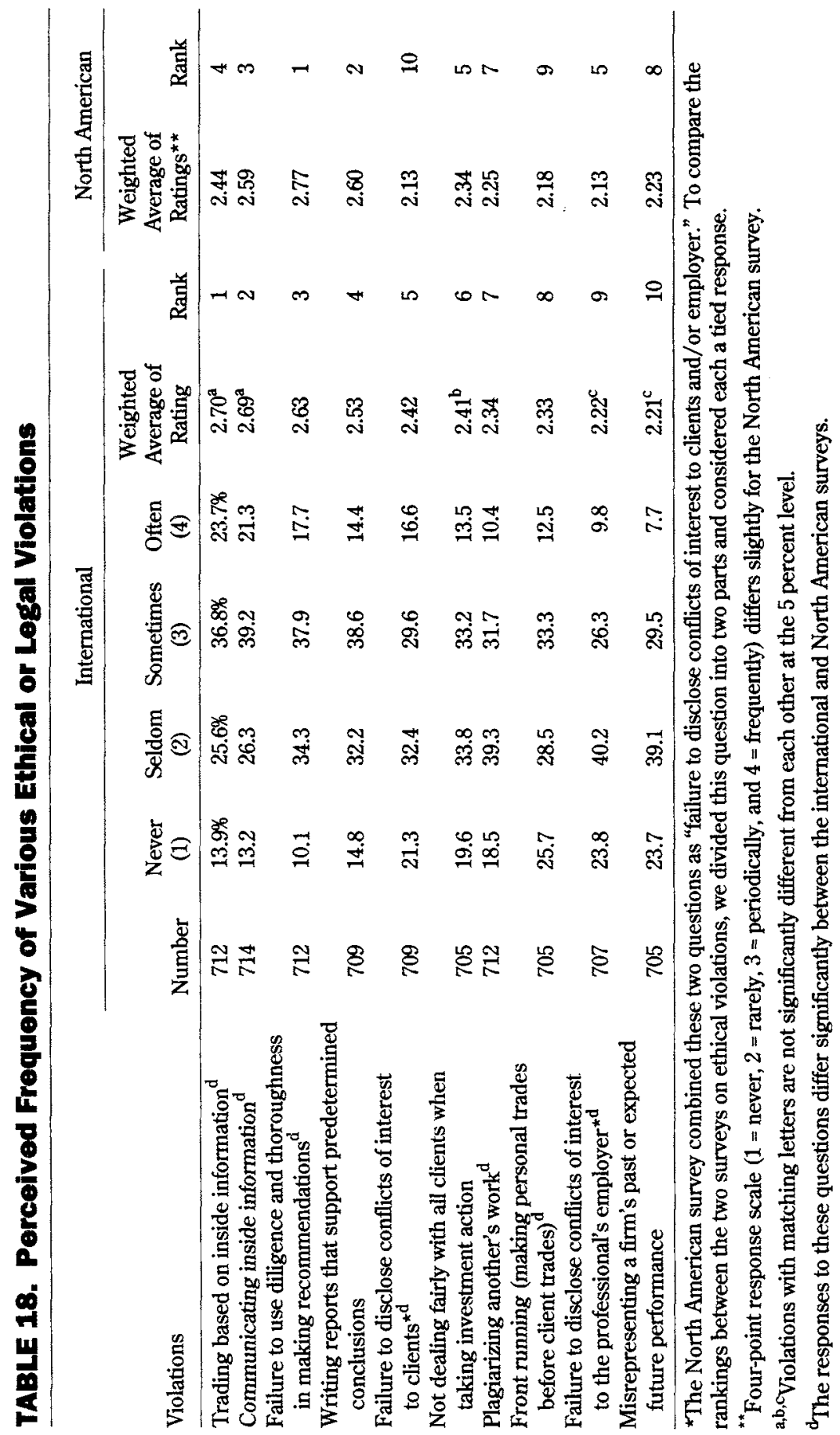


North American surveys shows no significant association (i.e., the Spearman rank correlation coefficient is 0.63 ). Chi-square tests of the frequency of each violation in the international survey and in the North American survey indicate a significant difference in the frequencies of the ethics violations in the following seven violations:

- trading based on inside information,

- communicating inside information,

- failure to use diligence and thoroughness in making recommendations,

- failure to disclose conflicts of interest to clients,

- plagiarizing another's work,

- front running, and

- failure to disclose conflicts of interest to the professional's employer.

Except for the last violation listed, the international respondents cited a higher frequency of ethics violations than their North American counterparts reported.

Table 19 presents the rankings of the ten ethical or legal violations for each country surveyed. For five of the eight countries, the top-ranked violation is trading based on inside information. Respondents in Japan and the United Kingdom rank insider trading as sixth and seventh, respectively, in order of frequency. The differences in rankings on insider trading among the countries surveyed may reflect the impact of different laws and sanctions. In both of those countries, failure to use diligence and thoroughness in making recommendations ranks as the most common ethical or legal violation in the investment profession. Respondents from Switzerland view the failure to disclose conflicts of interest to clients as the highest ranking violation. In four countries, misrepresenting a firm's past or expected future performance is the least frequent violation. Participants in two countries rank front running and failure to disclose conflict of interest to the professional's employer as the least frequently occurring violation.

\section{Personal Experiences with Unethical Behavior}

Survey participants were asked several questions about their recent personal experiences with perceived unethical behavior by others. In one question, respondents were asked if they had seen any unethical behavior by employees of their firm during the past 12 months, and if so, what action they took. As Table 20 shows, slightly over a quarter of the respondents reported seeing unethical behavior by an employee of their firm during the previous 12 months. When asked what action they took, the most common response is "took no action" (41.3 percent), followed by "discussed the unethical behavior 


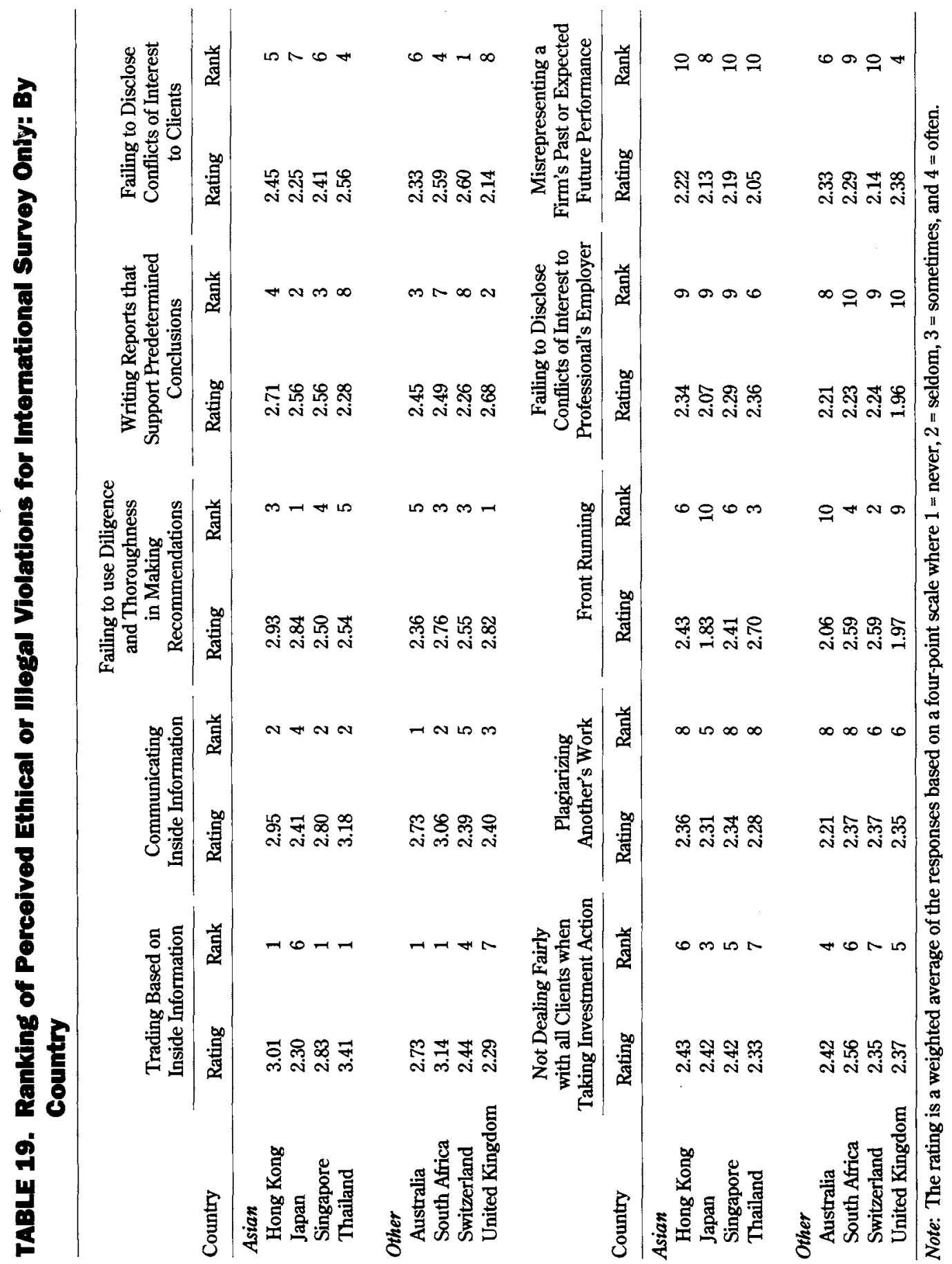


TABLE 20. Personal Observation of Unethlcal Behavlor

\begin{tabular}{|c|c|c|c|c|}
\hline \multirow[b]{2}{*}{ Question } & \multicolumn{2}{|c|}{ International } & \multicolumn{2}{|c|}{ North American } \\
\hline & Number & Percent $^{a}$ & Number & Percent $^{a}$ \\
\hline \multicolumn{5}{|l|}{$\begin{array}{l}\text { In the past } 12 \text { months, have you witnessed an } \\
\text { employee of your firm acting in a matter you } \\
\text { feel is unethical? }\end{array}$} \\
\hline Yes & 184 & $25.7 \%$ & 95 & $24.1 \%$ \\
\hline No & 438 & 61.3 & 300 & 75.9 \\
\hline Don't know & 93 & 13.0 & $\underline{\text { NA }}$ & $\mathrm{NA}$ \\
\hline Total & 715 & 100.0 & 395 & $\overline{100.0}$ \\
\hline \multicolumn{5}{|l|}{ If yes, what action did you take? $?^{\mathrm{a}}$} \\
\hline Took no action & 76 & 41.3 & 34 & 35.8 \\
\hline Discussed it with the person making the & 61 & 332 & 30 & 316 \\
\hline $\begin{array}{l}\text { Made the activity known to my } \\
\text { supervisor or other person }\end{array}$ & & 33.2 & 30 & 01.0 \\
\hline in the chain of command & 58 & 31.5 & 39 & 41.1 \\
\hline $\begin{array}{l}\text { Made the activity known to the ethics } \\
\text { compliance officer }\end{array}$ & 12 & 6.5 & 11 & 11.6 \\
\hline Other & 8 & 4.3 & $\underline{\mathrm{NA}}$ & NA \\
\hline Total & $\overline{215}$ & & $\frac{114}{114}$ & \\
\hline
\end{tabular}

$\mathrm{NA}=$ not asked in the survey.

${ }^{a}$ Respondents could indicate more than one action. Because the percentages are based only on those individuals who reported seeing unethical behavior (i.e., 184 respondents in the international survey and 95 respondents in the North American survey), the total exceeds 100 percent.

with the person making the infraction" (33.2 percent). Almost 32.0 percent of the respondents made the activity known to their supervisors or other persons in the chain of command. Only 6.5 percent informed their compliance officers of the violation.

A chi-square test shows no significant difference in the percentages of respondents from the international and from the North American surveys reporting that they have seen a colleague act unethically. To perform the chi-square test in this study, the "no" and "don't know" responses were combined into a single category because the respondents in the North American survey did not have a "don't know" option. About a quarter of the respondents from both surveys reported seeing such unethical behavior in the past 12 months. A chi-square test also shows no differences in the actions taken by those seeing a colleague act unethically between the respondents to the two surveys. For this chi-square test, the "other" category was omitted because the North American survey did not contain this category.

As Table 21 shows, the percentages of respondents witnessing unethical behavior by a colleague during the past 12 months vary widely among the eight 


\section{TABLE 21. Personal Observation of Unethical Behavior for International Survey: By Country}

\begin{tabular}{lc}
\hline Country & $\begin{array}{c}\text { Percent of Respondents Seeing } \\
\text { an Employee of Their Firms Act } \\
\text { Unethically in the Past 12 Months }\end{array}$ \\
\hline Asian & \\
Hong Kong & $28.7 \%$ \\
Japan & 20.2 \\
Singapore & 22.8 \\
Thailand & 25.6 \\
Other & \\
Australia & 30.3 \\
South Africa & 11.8 \\
Switzerland & 33.6 \\
United Kingdom & 27.2 \\
\hline
\end{tabular}

countries surveyed. Only 11.8 percent of the respondents from South Africa reported seeing unethical behavior by a colleague, compared with 33.6 percent of the respondents from Switzerland.

Survey participants were also asked if someone in the firm where they worked had ever asked them to do anything they considered unethical. As Table 22 shows, slightly more than 22 percent of the analysts and portfolio managers reported that they have been asked to do something unethical. Those who answered this question affirmatively were asked whether the request came from a person senior to, junior to, or at the same level as themselves within the organization. Most responded that the person was senior to them. Despite this finding, slightly less than 60 percent of the respondents believe that their firm's senior management seeks high ethical standards for all employees.

To perform the chi-square tests on the first and third questions in Table 22, the "no" and "don't know" responses were combined into a single category because the respondents in the North American survey did not have a "don't know" option. The chi-square tests show no significant differences between the international and North American surveys on the first two questions in Table 22, but the results do indicate that a significantly smaller percentage of international than North American respondents believe their firms' senior managers seek high ethical standards for employees. This finding suggests that senior management from countries represented in the international survey should take steps to improve the ethical standards within their firms.

Table 23 summarizes the results by country for the questions (1) "Have you 
TABLE 22. Requests to Do Something Unethical and Ethical Standards of Management

\begin{tabular}{|c|c|c|c|c|}
\hline \multirow[b]{2}{*}{ Question } & \multicolumn{2}{|c|}{ International } & \multicolumn{2}{|c|}{ North American } \\
\hline & Number & Percent $^{a}$ & Number & Percent $^{a}$ \\
\hline \multicolumn{5}{|c|}{$\begin{array}{l}\text { Have you ever been asked to do } \\
\text { anything you considered to be } \\
\text { unethical by someone in a firm } \\
\text { where you worked? }\end{array}$} \\
\hline Yes & 159 & $22.2 \%$ & 91 & $22.9 \%$ \\
\hline No & 541 & 75.7 & 307 & 77.1 \\
\hline Don't know & 15 & 2.1 & NA & NA \\
\hline Total & $\overline{715}$ & $\overline{100.0}$ & $\overline{398}$ & $\overline{100.0}$ \\
\hline \multicolumn{5}{|c|}{$\begin{array}{l}\text { If yes, was this person (or persons) } \\
\text { senior to you, junior to you, or } \\
\text { at the same level as you in the } \\
\text { organization? }\end{array}$} \\
\hline Senior to you & 141 & 88.7 & 84 & 92.3 \\
\hline Junior to you & 6 & 3.8 & 3 & 3.3 \\
\hline $\begin{array}{l}\text { Same level as you } \\
\text { Total }\end{array}$ & $\frac{19}{166}$ & 11.9 & $\frac{8}{95}$ & 8.8 \\
\hline \multicolumn{5}{|c|}{$\begin{array}{l}\text { In your opinion, does your firm's senior } \\
\text { management truly seek high ethical } \\
\text { standards from all emplovees? }\end{array}$} \\
\hline Yes & 426 & 59.8 & 343 & 86.6 \\
\hline No & 150 & 21.1 & 53 & 13.4 \\
\hline Don't know & $\underline{136}$ & 19.1 & NA & $\mathrm{NA}$ \\
\hline Total & $\frac{212}{712}$ & 100.0 & 396 & 100.0 \\
\hline
\end{tabular}

$\mathrm{NA}=$ not asked in the survey.

The percentages reflect the answers of only those individuals who reported being asked to do something that they considered unethical (i.e., 159 respondents in the international survey and 91 respondents in the North American survey). Because respondents could indicate more than one level, the total exceeds 100 percent.

${ }^{\mathrm{b}}$ The responses to this question differ significantly between the international and North American surveys.

ever been asked to do anything you considered to be unethical by someone in a firm where you work?" and (2) "In your opinion, does your firm's senior management truly seek high ethical standards for all employees?" The percentage of respondents asked to do something considered unethical is lower in the Asian countries, except Japan, than in the other countries. For example, fewer than 20 percent of the respondents from Thailand, Singapore, and Hong Kong reported someone asking them to do something unethical, whereas more than 20 percent of the respondents from the remaining countries surveyed reported experiencing such events. The respondents from the four 


\begin{tabular}{|c|c|c|}
\hline Country & $\begin{array}{l}\text { Something Unethical in a } \\
\text { Firm Where They Worked }\end{array}$ & $\begin{array}{l}\text { Respondents Who Believe Their } \\
\text { Firm's Senior Management Seeks } \\
\text { High Ethical Standards of Employees }\end{array}$ \\
\hline \multicolumn{3}{|l|}{ Asian } \\
\hline Hong Kong & $19.4 \%$ & $51.2 \%$ \\
\hline Japan & 28.4 & 56.4 \\
\hline Singapore & 16.8 & 53.0 \\
\hline Thailand & 12.8 & 56.4 \\
\hline \multicolumn{3}{|l|}{ Other } \\
\hline Australia & 24.2 & 75.8 \\
\hline South Africa & 23.5 & 78.4 \\
\hline Switzerland & 26.8 & 54.0 \\
\hline United Kingdom & 25.0 & 80.2 \\
\hline
\end{tabular}

Asian countries believe that a smaller percentage of their senior management seek high ethical standards for employees than do those from the other countries except Switzerland. More than three-quarters of the respondents from Australia, South Africa, and the United Kingdom believe their senior managers seek high ethical standards. 


\section{Summary and Conclusions}

This report of the results of an international ethics survey of securities analysts and portfolio managers extends a previous study (Veit and Murphy 1992) that focused on U.S. and Canadian investment professionals. The opinions expressed by the respondents to the current survey provide a cross-section of opinions about ethical issues on the part of the investment profession in the countries surveyed. This survey also provides an opportunity to compare ethical perceptions and behavior between investment professionals inside and outside North America.

Based on the statistical tests, several key differences exist between the responses from the international and the North American surveys.

- The respondents to the international survey are significantly younger, have less experience in the investment business, are less well educated, and hold fewer CFA charters than respondents in the North American survey. The type of firm and the number of analysts and portfolio managers in each firm also differ significantly between the two surveys. Most participants in the international survey are employed by investment companies or mutual funds, and fewer are employed by investment counseling and money management firms than in the North American survey. In addition, more participants in the international survey than in the North American survey are employed by very large firms (those having 40 or more analysts).

- A much larger percentage of the international respondents than of their North American counterparts believe that ethical standards in the investment profession improved during the previous ten-year period. The international respondents are also more positive about future improvement in ethical behavior.

- The importance attached to various sources of an investment professional's training and education differs significantly between the two groups of respondents. Both groups, however, view senior management as the most important source.

- The importance attached to various deterrents to unethical behavior differs significantly between the two surveys. A higher percentage of 
international than of North American respondents believe that concern about sanctions from self-regulatory organizations and having a published code of ethics are greater deterrents to unethical behavior than other factors. Conversely, a higher percentage of North American than of international respondents believe that moral and religious beliefs and concern that family or friends will find out are greater deterrents than other factors.

- Compared with their North American counterparts, a much smaller percentage of international firms publish a code of ethics and require their investment professionals periodically to read the code endorsed by the firm.

- A much smaller percentage of respondents to the international survey report that their firms have a compliance officer. The positions (ranks) of the compliance officers also differ significantly between the two surveys. Far more directors are shown to be compliance officers in the international survey than in the North American survey. Conversely, far more executive or senior vice presidents or vice presidents are shown to be compliance officers in the North American survey than in the international survey.

- The frequencies of seven of the ten ethics violations differ significantly between the two groups. Compared with their North American counterparts, the international respondents cite a higher frequency of ethical violations for trading based on inside information, communicating inside information, failure to disclose conflicts of interest to clients, plagiarizing another's work, front running, and failure to disclose conflicts of interest to the professional's employer. Failure to disclose conflicts of interest to the professional's employer is a more frequently cited violation in the North American survey than in the international survey.

- A much smaller percentage of international respondents believe their firms' senior managers seek high ethical standards for all employees than the percentage for North American respondents.

The major findings of the survey regarding ethical issues among the investment professionals in the eight countries surveyed are as follows:

- More than 65 percent of the respondents believe that ethical standards of investment professionals in their countries have improved during the past ten years. Respondents are even more optimistic about future improvements in ethical standards.

- Respondents perceive that the ethical behavior of investment professionals ranks about midway among six occupational groups: below engineers and commercial bankers but above lawyers, corporate man- 
agers, and politicians.

- Respondents believe that an investment professional's training and education in ethical behavior should come primarily from senior management by example and the employing firm through training programs. Respondents also believe that these two sources currently are not as effective as they should be. Respondents perceive the most effective source of useful training and education in ethical behavior to be the home environment.

- More than a quarter of the respondents report witnessing a colleague acting unethically during the previous 12 months. Their most common response was to take no action; the next most common response was to discuss the behavior with the person who made the infraction.

- More than a fifth of the respondents report being asked to do something unethical by someone in a firm where they worked. This individual is most commonly senior to them.

- The two most commonly reported ethical or legal violations by investment professionals involve inside information-either trading based on inside information or communicating inside information.

- The two most important deterrents to unethical behavior are concern about disciplinary action by the professional's employer and concern about sanctions from government agencies.

- Respondents report that most of their firms neither have their own codes of ethics nor require investment professionals to read a code of ethics. Almost half the firms have an officer to ensure compliance with legal and ethical standards.

- Most respondents believe that their firms' senior management seeks high ethical standards for all employees.

The findings of the current survey suggest that, despite the progress made in improving ethical standards among investment professionals worldwide, additional changes are necessary to improve the ethical behavior and enhance the reputation of the profession. Evidence suggests that senior managers must by example set the tone for ethical behavior. Employing firms also need to provide effective training programs to help ensure that investment professionals act ethically. For example, investment professionals need to know not only the ethical standards of their firms but also how to respond properly after observing unethical practices. The high incidence of ethical violations reported in the international survey, especially those involving inside information, implies that sufficient deterrents are not in place in some organizations. Endorsing a code of ethics and having a compliance officer are not enough to ensure uniform observance of legal and ethical standards. In addition to 
providing ethical training and education, organizations employing investment professionals need to establish and enforce appropriate disciplinary procedures to deal with those who violate ethical standards. 


\section{Appendix: Ethics in the Investment Profession Survey}

This survey is being conducted to help the investment and academic communities better understand the attitudes and practices of investment professionals relating to ethical practices in the investment profession.

Definitions:

Ethical means abiding by accepted standards of professional conduct.

Standards of professional conduct are standards described and encouraged by a professional organization such as the Association for Investment Management and Research (AIMR).

Investment professionals refers to all professionals who work in the investment field, including, but not limited to, securities analysts, portfolio managers, and officers of companies specializing in the management of financial assets and/or the selling of advice or research relating to the management of financial assets.

Q-1 In your opinion, how have the ethical standards of investment professionals in your country changed over the past ten years?

They have improved

They have deteriorated

471

They have remained unchanged

46

No opinion

Total

145

$\frac{54}{716}$

Q-2 In your opinion, how are the ethical standards of investment professionals in your country likely to change over the next ten years?

I expect them to improve

I expect them to deteriorate

I expect them to remain unchanged

No opinion

Total

559

46

88

$\frac{23}{716}$ 
Q-3 How do you perceive the actual ethical behavior of most people in the following professional groups?

$\begin{array}{lccccc} & \begin{array}{c}\text { Not } \\ \text { Ethical }\end{array} & \begin{array}{c}\text { Somewhat } \\ \text { Ethical }\end{array} & \begin{array}{c}\text { Moderately } \\ \text { Ethical }\end{array} & \begin{array}{c}\text { Highly } \\ \text { Ethical }\end{array} & \text { Total } \\ \text { Lawyers } & 53 & 235 & 315 & 106 & 709 \\ \text { Commercial bankers } & 27 & 216 & 386 & 82 & 711 \\ \text { Corporate managers } & 36 & 286 & 349 & 39 & 710 \\ \text { Investment professionals } & 25 & 213 & 418 & 52 & 708 \\ \text { Politicians } & 348 & 247 & 89 & 28 & 712 \\ \text { Engineers } & 17 & 103 & 399 & 184 & 703\end{array}$

Q-4 In your opinion, how much of an investment professional's training and education about ethical behavior should come from each of the following sources?

$\begin{array}{lrrrrr} & \text { None } & \begin{array}{c}\text { Small } \\ \text { Amount }\end{array} & \begin{array}{c}\text { Moderate } \\ \text { Amount }\end{array} & \begin{array}{c}\text { Large } \\ \text { Amount }\end{array} & \text { Total } \\ \begin{array}{lrrrr}\text { School, college, or } \\ \quad \text { university }\end{array} & 25 & 125 & 326 & 240 & 716 \\ \begin{array}{l}\text { Home environment } \\ \text { Professional organizations }\end{array} & 20 & 83 & 203 & 407 & 713 \\ \begin{array}{l}\text { Employing firm } \\ \quad \text { (training programs) }\end{array} & 7 & 66 & 243 & 396 & 714 \\ \begin{array}{l}\text { Senior management } \\ \quad \text { (by example) }\end{array} & 4 & 59 & 247 & 401 & 714 \\ \begin{array}{l}\text { Religious education } \\ \text { Other (specify) }\end{array} & 166 & 213 & 150 & 517 & 713 \\ & 25 & 9 & 17 & 149 & 704 \\ \end{array}$

Q-5 In your opinion, how effective has each of the following been in providing you with useful training and education about ethical behavior?

$\begin{array}{lrrccc} & \begin{array}{c}\text { Not } \\ \text { Effective }\end{array} & \begin{array}{c}\text { Slightly } \\ \text { Effective }\end{array} & \begin{array}{c}\text { Moderately } \\ \text { Effective }\end{array} & \begin{array}{c}\text { Highly } \\ \text { Effective }\end{array} & \text { Total } \\ \begin{array}{lrrrr}\text { School, college, or } \\ \text { university }\end{array} & 147 & 245 & 256 & 68 & 716 \\ \quad \text { Home environment } & 32 & 75 & 194 & 413 & 714 \\ \begin{array}{l}\text { Professional organizations } \\ \text { Employing firm }\end{array} & 45 & 158 & 275 & 234 & 712 \\ \quad \text { (training programs) } & 119 & 245 & 223 & 122 & 709 \\ \quad \begin{array}{l}\text { Senior management } \\ \quad \text { (by example) }\end{array} & 99 & 233 & 242 & 137 & 711 \\ \quad \begin{array}{l}\text { Formal religious education } \\ \text { Other (if specified in Q-4) }\end{array} & 234 & 179 & 160 & 123 & 696 \\ \end{array}$

Q-6 In your opinion, how important is each of the following in deterring the unethical behavior of investment professionals? 


$\begin{array}{lccccc} & \begin{array}{c}\text { Not } \\ \text { Effective }\end{array} & \begin{array}{c}\text { Slightly } \\ \text { Effective }\end{array} & \begin{array}{c}\text { Moderately } \\ \text { Effective }\end{array} & \begin{array}{c}\text { Highly } \\ \text { Effective }\end{array} & \text { Total } \\ \begin{array}{c}\text { Moral or religious } \\ \text { beliefs }\end{array} & 80 & 184 & 226 & 218 & 708 \\ \begin{array}{c}\text { Concern about sanctions } \\ \text { from state or provincial }\end{array} & 29 & 117 & 245 & 322 & 713 \\ \begin{array}{c}\text { agencies } \\ \begin{array}{c}\text { Concern about sanctions } \\ \text { from self-regulatory }\end{array}\end{array} & 38 & 152 & 325 & 199 & 714 \\ \begin{array}{c}\text { agencies such as the AIMR } \\ \begin{array}{c}\text { Concern that family or } \\ \text { friends will find out }\end{array}\end{array} & 71 & 243 & 270 & 129 & 713 \\ \begin{array}{c}\text { Concern about disciplinary } \\ \text { action by the profes- }\end{array} & 12 & 70 & 301 & 330 & 713 \\ \begin{array}{c}\text { sional's employer } \\ \text { Having a published code } \\ \text { of ethics }\end{array} & 71 & 237 & 264 & 139 & 711\end{array}$

Q-7 Does your firm publish its own code of ethics separate from that of any professional organization's code of ethics?

$\begin{array}{lr}\text { Yes } & 291 \\ \text { No } & 370 \\ \text { Don't know } & 55 \\ \text { Total } & 716\end{array}$

Q-8 If your firm endorses a code of ethics (either its own or that of a professional organization), does it require its investment professionals to read the code of ethics?

$\begin{array}{lr}\text { Yes } & 321 \\ \text { No (go to Q-9) } & 163 \\ \text { Don't know (go to Q-9) } & 69 \\ \text { Not applicable (go to Q-9) } & \mathbf{1 5 5} \\ \text { Total } & 708\end{array}$

If yes, how frequently does your firm require investment professionals to read the code of ethics it endorses?

$\begin{array}{lr}\text { One time only, when employment begins } & 178 \\ \text { Once each year } & 82 \\ \text { Once every two years } & 9 \\ \text { Other (specify) } & 51 \\ \text { Total } & 320\end{array}$

If $y$ es, are the investment professionals in your firm required to provide written verification that they have read and will comply with the code of ethics it endorses?

$\begin{array}{lr}\text { Yes } & 201 \\ \text { No } & 115 \\ \text { Don't know } & \underline{9} \\ \text { Total } & 325\end{array}$


Q-9 Does your firm have a compliance officer to ensure legal and ethical standards are maintained?

Yes

No (go to Q-10)

Don't know (go to Q-10)

Total

If yes, do you know the name of your firm's compliance officer?

Yes

No (go to Q-10)

293

Total

$\frac{68}{361}$

If $y e s$, what is the position of your firm's compliance officer? [Note: The titles for the positions of the compliance officer differed in various countries.]

$\begin{array}{lr}\text { Chairs the board of directors } & 1 \\ \text { Director } & 84 \\ \text { President } & 23 \\ \text { Executive or senior vice president } & 55 \\ \text { Vice president } & 59 \\ \text { Below the vice president level } & 31 \\ \text { Other (specify) } & 39 \\ \text { Don't know } & \underline{12} \\ \text { Total } & \mathbf{3 0 4}\end{array}$

Q-10 Listed below are several types of behavior that are considered unethical and/or illegal in the investment profession. Based on your personal experience or observation, indicate how often these violations occur.

\begin{tabular}{|c|c|c|c|c|c|}
\hline & Never & Seldom & Sometimes & Often & Total \\
\hline Trading based on inside information & 99 & 182 & 262 & 169 & 712 \\
\hline Communicating inside information & 94 & 188 & 280 & 152 & 714 \\
\hline $\begin{array}{l}\text { Front running (making personal } \\
\text { trades before client trades) } \\
\text { Writing reports that support } \\
\text { predetermined conclusions }\end{array}$ & 181 & 201 & 235 & 88 & 705 \\
\hline $\begin{array}{l}\text { Plagiarizing another's work } \\
\text { Failing to use diligence and }\end{array}$ & 105 & 228 & 274 & 102 & 709 \\
\hline $\begin{array}{l}\text { thoroughness in making } \\
\text { recommendations } \\
\text { Misrepresenting a firm's past }\end{array}$ & 72 & 244 & 270 & 126 & 712 \\
\hline $\begin{array}{l}\text { or expected future performance } \\
\text { Not dealing fairly with all clients }\end{array}$ & 167 & 276 & 208 & 54 & 705 \\
\hline $\begin{array}{l}\text { when taking investment action } \\
\text { Failing to disclose conflicts of }\end{array}$ & 138 & 238 & 234 & 95 & \\
\hline $\begin{array}{l}\text { interest to clients } \\
\text { Failing to disclose conflicts of }\end{array}$ & 151 & 230 & 210 & 118 & \\
\hline employer & 168 & 284 & 186 & 69 & \\
\hline Other (specify) & 7 & 1 & 5 & 9 & 22 \\
\hline
\end{tabular}


Q-11 In the past 12 months, have you witnessed an employee of your firm acting in a manner you feel is unethical?

Yes

No (go to Q-12)

Don't know (go to Q-12)

Total

184
438
$\frac{93}{715}$

If yes, what action did you take? (Circle the number of all that apply). Discussed it with the person making the infraction

Made the activity known to my supervisor or other person in the chain of command

Made the activity known to the ethics compliance officer

Took no action

Other (specify)
61

58

12

76

8

Q-12 Have you ever been asked to do anything you considered to be unethical by someone in a firm where you worked?

Yes 159

No (go to Q-13)

541

Don't know (go to Q-13) Total

$\frac{15}{715}$

If yes, was this person (or persons) senior to you, junior to you, or at the same level as you in the organization? (Circle the number of all that apply).

Senior to you

Junior to you

Same level as you

Q-13 In your opinion, does your firm's senior management truly seek high ethical standards for all employees?

$\begin{array}{ll}\text { Yes } & 426 \\ \text { No } & 150 \\ \text { Don't know } & 136 \\ \text { Total } & 712\end{array}$

Q-14 With what type of firm are you now employed?

Broker or investment bank

Investment company or mutual fund

131

Investment counseling and money management 121

Insurance company

Commercial bank

Other (specify) 
Q-15 On which side of financial transactions is most of your professional activity involved, the "buy-side" activities (managing portfolios) or "sell-side" activities (marketing securities or conducting research)?

"Buy side"

"Sell side"

404

Other (specify)

262

Total

$\frac{49}{715}$

Q-16 About how many analysts and portfolio managers does your firm employ?

Less than 10

256

From 10 to 19

137

From 20 to 29

53

From 30 to 39

27

40 or more

$\frac{241}{714}$

Total

714

Q-17 How many years have you been employed in the investment business?

Less than 5 years 337

5 to 9 years 268

10 to 14 years 91

15 to 19 years $\quad 8$

20 to 24 years 4

25 to 29 years 3

$\begin{array}{lr}30 \text { years or more } & -\frac{1}{712}\end{array}$

Q-18 What is your highest earned academic degree?

High school diploma

Bachelors degree

Masters degree

315

Doctorate

17

Other

$\frac{31}{716}$

Total

Q-19 Have you earned the CFA designation or are you a candidate for that designation?

I am a CFA charterholder $\quad 158$

I am a CFA candidate $\quad 544$

Neither apply to me $\quad \underline{15}$

Total $\quad \frac{15}{717}$

Q-20 What is your gender?

Male

Female

557

Total

$\underline{161}$

718 


\section{Q-21 How old are you?}

$\begin{array}{lr}\text { Under } 25 \text { years } & 44 \\ 26 \text { to } 35 \text { years } & 562 \\ 36 \text { to } 45 \text { years } & 105 \\ 46 \text { to } 55 \text { years } & 5 \\ 56 \text { to } 65 \text { years } & 2 \\ \text { Over } 65 \text { years } & 0\end{array}$

Q-22 In what country are you primarily employed? (Specify)

Australia

Hong Kong

37

Japan

128

South Africa

Singapore

97

Switzerland

51

Thailand

United Kingdom

United States

Other

Total

Of what country are you a citizen? (Specify all that apply) Australia

Hong Kong

Japan

South Africa

Singapore

Switzerland

145

127

Thailand

38

86

United Kingdom

1

United States

Other

Total

Q-24 Would you like to receive a copy of the survey results?

Yes

648

No

Total

$\frac{64}{712}$ 


\section{References}

Bauman, W. Scott. 1980. Professional Standards in Investment Management. Charlottesville, Va.: The Financial Analysts Research Foundation.

Casey, John L. 1988. Ethics in the Financial Marketplace. New York: Scudder, Stevens \& Clark.

Cohen, Jeffrey R., Laurie W. Pant, and David J. Sharp. 1992. "Cultural and Socioeconomic Constraints on International Codes of Ethics: Lessons from Accounting." Journal of Business Ethics (September):687-700.

Cree, Murray, and Geoffrey Baring. 1991. "Desperately Seeking Ethics." Australian Accountant (July):25-26.

Dimma, William A. 1991. "The Decline of Ethics." Vital Speeches (February 1):244-47.

Dunleavy, G.D. 1991. "Business and Professional Ethics in Hong Kong." Perspectives on the Professions. Center for the Study of Ethics in the Professions, Illinois Institute of Technology (August): 4-5.

"Fallen Angels." 1991. Asian Finance (July 15):6-7.

Frankhauser, Mahlon M., and David S. Frye. 1988. "Front Running." The Review of Securities \& Commodities Regulation, Standard \& Poor's Corporation (October 19).

Gillis, John G., and Iver J. Kern. 1986. "New Soft Dollar Rules." Financial Analysts Journal (September/October):12-15.

Harlan, Christi. 1993. "SEC Turns Up Heat on Brokers' Commissions." Wall Street Journal (December 2):C1.

King, Paul. 1992. "ING Loses Its Zing." Euromoney (October):18-19.

Lee, D. Scott, Wayne H. Mikkelson, and Megan M. Partch. 1992. "Managers' Trading Around Stock Repurchases." The Jourmal of Finance (December):1947-61.

Markowitz, Harry M. 1992. "Markets and Morality." The Journal of Portfolio Management (Winter):84-93.

Morley, Alfred C. 1987. "Ethical Standards for Investment Professionals." Business Economics (October):27-34

Sommar, Jessica. 1991. "Affluent Investors Give Brokers High Marks for Ethics." Investment Dealers Digest (October 28):9.

Stewart, James. 1991. Den of Thieves. New York: Simon and Schuster.

Terpstra, David E., Mario G.C. Reyes, and Donald W. Bokor. 1991. "Predictors of Ethical Decisions Regarding Insider Trading." Journal of Business Ethics (September):699-710.

Veit, E. Theodore, and Michael R. Murphy. 1992. Ethics in the Investment Profession: A Survey. Charlottesville, Va.: The Research Foundation of the Institute of Chartered Financial Analysts.

Walsh, Sharon. 1991. "A Lawyer and the Brewing Scandal: Thomas Ward Fights Extradition over $\$ 8.3$ Million Fee in Takeover Deal." Washington Post (March 4):F1. 